\title{
The Efficiency of Controlling Corporate Self-Dealing: Theory Meets Reality
}

\author{
Zohar Goshen $\dagger$
}

\section{TABLE OF CONTENTS}

Introduction

I. The Problem of Self-Dealing and Possible Solutions ..................... 399

A. Self-Dealing and the Voting Mechanism................................... 399

B. Possible Solutions to Self-Dealing........................................... $40 \mathrm{I}$

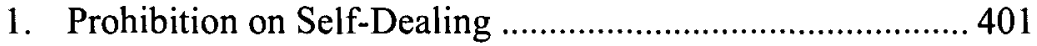

2. The Majority-of-the-Minority Vote.................................... 402

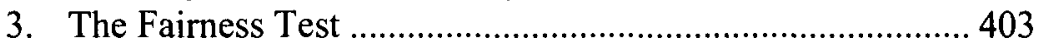

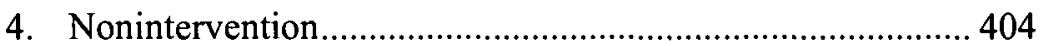

1I. Characteristics of the Preferred Solutions …................................... 408

A. Property Rules Versus Liability Rules....................................... 408

B. Subjective Versus Objective Valuations................................... 410

C. The Division of the Surplus ..................................................... 411

1. The Direct Surplus Division............................................. 412

2. The Frequency of Transactions ........................................ 413

III. Factors Determining the Right Solution........................................... 414

A. Negotiation Costs................................................................... 415

B. Adjudication Costs....................................................... $4 \mathrm{I} 8$

C. Market Mechanisms.............................................................. 421

1. The Market for Corporate Control .................................... 421

2. The Capital Market.............................................................. 423

Copyright $(2003$ California Law Review, Inc. California Law Review, Inc. (CLR) is a California nonprofit corporation. CLR and the authors are solely responsible for the content of their publications.

$\dagger$ Visiting Professor of Law, Columbia Law School, and Professor of Law, Faculty of Law, Hebrcw University, Jcrusalem. J.S.D., Yale Law School; LL.M., Yale Law School; LL.B., Hebrew University, Jerusalcm.

For valuable eomments and suggestions I wish to thank Yishai Beer, Barry Adler, Eyal Benvenisti, Lisa Bernstein, Bernard Black, Hanoch Dagan, Robert Daines, Luca Enriques, Jesse Fried, Ronald Gilson, Victor Goldberg, Henry Hansmann, Alon Harel, Marcel Kahan, Ehud Kamar, Avery Katz, Kon Sik Kim, Michael Klausner, Gideon Parchomovski, Katharina Pistor, Ariel Porat, Eric Posner, Uriel Procaecia, Edward Rock, Mark Roe, Roberta Romano, Alex Stein, Charles Yablon, Omri Yadlin, the seminar participants at Columbia Law Sehool, Hebrew University Faeulty of Law, Stanford University Sehool of Law, and Tel Aviv University Faculty of Law. For excellent research assistance, I thank Laurencc Burger, Rebecca Hornstein, Yael Lustmann, and Krishna Veerarghavan. 


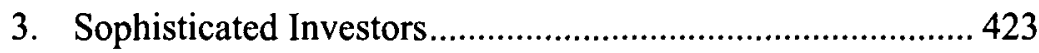

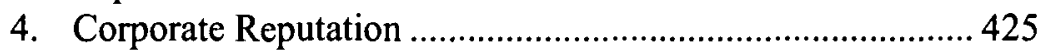

D. A Comparative Overview and Analysis ................................... 425

1. The United States (Delaware) ......................................... 426

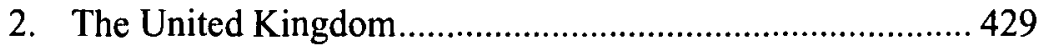

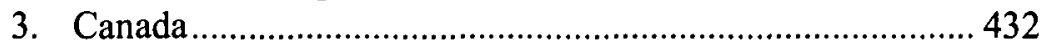

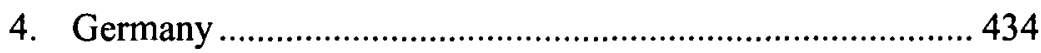

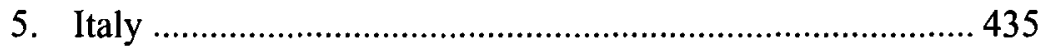

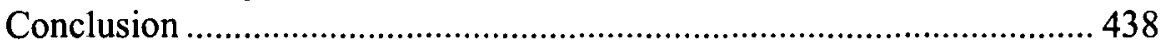




\section{The Efficiency of Controlling Corporate Self-Dealing: Theory Meets Reality}

\section{Zohar Goshen}

Corporate self-dealing may be controlled either by legal rules or by the unconstrained forces of the market. The regulatory options include an absolute prohibition on self-dealing, a prohibition on voting with conflicting interests (the "majority of the minority" requirement), and an imposition of fairness duties (the "fairness test"). Using an economic analysis, this Article presents a unique theoretical framework for evaluating the relative efficiency of the attempts to control self-dealing adopted by five countries: The United States (Delaware in particular), the United Kingdom, Canada, Germany, and Italy.

The Article's analysis of the self-dealing problem is based on the novel theory that legal protections can be classified into "property rules" or "liability rules" not only in the context of individual rights but also in the context of group rights. Applying this theory to self-dealing transactions, in which the "group" is composed of the minority shareholders, the author demonstrates that each of the two most effective solutions to the self-dealing problem can be classified as either a property rule or a liability rule. The requirement of a majority-of-the-minority vote, which prevents any transaction from proceeding without the minority group's consent, can be defined as a property rule. The fairness test, which allows transactions to be imposed on an unwilling minority group but ensures that the minority receives adequate compensation in objective market-value terms, can be defined as a liability rule.

The Article then analyzes the choice between these two solutions as a choice between a property rule and a liability rule. The author shows that the choice between the two types of rules-property or liability-is a function of the total transaction costs in a particular legal system. These transaction costs include the negotiation costs arising from a property rule, the adjudication costs associated with a liability rule, and several jurisdiction-specific factors, including the efficacy of the judicial system and the efficiency of market mechanisms (for example, the market for corporate control, the efficiency of the capital market, and the type of investors active in the market). 
The Article arrives at three principal conclusions. First, corporate laws must incorporate some form of minority protection against selfdealing as a mandatory rule. Second, because of the transaction costs associated with each means of legal protection, there is no single efficient solution suitable for every jurisdiction; any solution chosen to cope with the self-dealing problem must take into account the relevant local conditions. Third, Delaware's rules governing self-dealing, which were believed to be indeterminate and opaque, are shown, for the first time, to be efficient and coherent.

\section{INTRODUCTION}

Corporate self-dealing arises in transactions involving a conflict of interest between a member of the corporation and the corporation.' Selfdealing is a complex problem that may be found in many corporate actions and deals such as those between a corporation and the party controlling it, a subsidiary, a director or officer of the corporation, or any other entity in which a shareholder may have an interest. ${ }^{2}$

Corporate law addresses the self-dealing problem in several ways. In Delaware, the most important state of incorporation in the United States, self-dealing transactions are subject to the "entire fairness" test: The interested party must demonstrate that the transaction is the product of "fair

1. The conflict-of-interest problem is only one manifestation of the fundamental "agency problem" pervading corporate law. See M. C. Jensen \& W. H. Meckling, Theory of the Firm: Managerial Behavior, Agency Costs and Ownership Structure, 3 J. FiN. ECoN. 305 (1976). General background on the issues of self-dealing and duty of loyalty can be found in any textbook on corporate law. See, e.g., William L. Cary \& Melvin A. Eisenberg, Cases and Materials on Corporations 647-809 (7th ed. 1995).

2. See, e.g., Kahn v. Tremont Corp., 694 A.2d 422 (Del. 1997) (transaction in which a corporation and its board of directors purchased shares of a corporation where $90 \%$ of its shares were owned by a trust for the family of a board member); Kahn v. Lynch Communication Sys., 638 A.2d 1110 (Del. 1994) (merger between a controlling shareholder and the company); Wiegand v. Berry Petroleum Co., No. 9316, 1991 Del. Ch. LEXIS 37 (Del. Ch. Mar. 27, 1991) (transaction in which a majority shareholder purchased all minority shares and merged the corporation with the majority's wholly owned subsidiary); Rosenblatt v. Getty Oil Co., 493 A.2d 929 (Del. 1985) (a stock-for-stock merger between the majority and the company); Levien v. Sinclair Oil Corp., 261 A.2d 911 (Del. Ch. 1969) (a dividend distribution decision relating to conflicted parent-subsidiary relationships); David J. Greene \& Co. v. Dunhill Int'l Inc., 249 A.2d 427 (Del. Ch. 1968) (a merger between two corporations, wherein a majority of directors from one corporation were also directors and officers of the merging company); Warshaw v. Calhoun, 221 A.2d 487 (Del. 1966) (private holding company sold its subscription rights to an underwriter rather than passing the rights on to its stockholders); Ripley $v$. Int'l Rys. of Cent. Am., 171 N.E.2d 443 (N.Y. 1960) (transaction between a railway corporation and its dominant shareholder); Sterling v. Mayflower Hotel Corp., 93 A.2d 107 (Del. Ch. 1952) (merger between a parent and a subsidiary); Gottlieb v. Heyden Chem. Corp., 91 A.2d 57 (Del. 1952) (decision by certain stockholders of a corporation to issue themselves stock options without obtaining stockholder ratification). 
dealing" and reflects a "fair price." 3 While this fairness test is the dominant tool for adjudicating self-dealing in the overwhelming majority of U.S. jurisdictions ${ }^{4}$ it is by no means the only possible solution to the problem posed by conflicting interests in the corporate setting. In Canada, for example, self-dealing transactions may be performed only with the approval of the disinterested shareholders. ${ }^{5}$ This requirement is often referred to as the "majority of the minority" rule.

How effective are these solutions in contending with the self-dealing problem? What are the economic implications of the different approaches? What factors should determine which approach is preferable? Despite the importance of these questions, comprehensive research and analyses of the self-dealing problem are lacking. ${ }^{6}$ As this Article will show, the absence of an analytical framework has led scholars to assert that Delaware's intricate regulations concerning corporate self-dealing7 are "opaque" and exhibit a high degree of "indeterminacy." 8 Yet, when Delaware's rules are analyzed under the framework proposed in this Article, they are shown to be efficient and coherent. ${ }^{9}$

3. Weinberger v. UOP, Inc., 457 A.2d 701, 710-11 (Del. 1983) (holding that a merger flawed by conflicts of interest and by denial of critical information to minority shareholders was not fair to plaintiff and other minority shareholders of defendant corporation).

4. See Cal. Corp. Code $\S 310$ (West 2000); Del. Code Ann. tit. $8 \S 144$ (2001); N.Y. Bus. Corp. LaW $\S 713$ (McKinney 2001); Model Bus. CorP. ACt $\S 8.31$ (1984); Principles of Corp. GoverNaNCE $\$ \S 1.09,1.20,5.02,5.07$ (1994).

5. See Ronald J. Daniels \& Jeffrey G. Macintosh, Toward a Distinctive Canadian Corporate Law, 29 OsGoode Hall L.J. 863, 929 (199I).

6. The existing works focus on other aspects of the problem. See Alison Grey Anderson, Conflicts of Interest: Efficiency, Fairness and Corporate Structure, 25 UCLA L. REv. 738 (1978) (suggesting "why certain conflicts of interest are singled out for special regulation"); Harold Marsh, Jr., Are Directors Trustees? Conflicts of Interest and Corporate Morality, 22 Bus. Law 35 (1966) (providing a historical perspective).

7. Although the basic rule in Delaware is the fairness test, when the transaction has been approved by a majority of the disinterested shareholders, Delaware law alters its requirements in one of two ways. In deals involving a controlling shareholder, the "entire fairness" test is still applied, but the burden of demonstrating the transaction's unfairness shifts to the party opposing the transaction. See $K a h n, 638$ A.2d at 1122 . Where the interested party is a director or officer who is not a controlling owner, the transaction is assessed by the business judgment rule, instead of the more rigid "entire fairness" test. See Michelson v. Duncan, 407 A.2d 211 (Del. 1979) (holding that where there has been independent stockholder ratification of interested director action, the objecting stockholder has the burden of showing that no person of ordinary sound business judgment would say that the consideration received for the options was a fair exchange for the options granted). See infra Part III.D.1.

8. Ehud Kamar, A Regulatory Competition Theory of Indeterminacy in Corporate Law, 98 Colum. L. Rev. 1908, 1939 (1998) (arguing that "[t]he competitive advantage that Delaware derives from legal indeterminacy may have shaped its law indirectly"); Michael Klausner, Corporations, Corporate Law, and Networks of Contracts, 81 VA. L. REv. 757 (1995) (discussing the benefits of judicial interpretation of contract terms under Delaware corporate law and arguing that the contractarian paradigm overlooks the network externality value of a contract term widely adopted by a number of firms); Edward B. Rock, Saints and Sinners: How Does Delaware Corporate Law Work?, 44 UCLA L. REv. 1009 (1997) (discussing the unique style of Delaware courts' writings).

9. See infra Part III.D.1. 
This Article offers a comprehensive framework for understanding the variety of rules governing self-dealing. This framework is founded on a novel application of a familiar conceptual classification of legal protections into "property rules" or "liability rules." This classification, which is wellknown in the context of analyzing individuals' rights, ${ }^{10}$ is applied in the context of group rights. Under this framework, the rules regulating corporate self-dealing are shown to provide the disinterested group (the minority) with protection against expropriation of their corporate assets in the form of either a "property rule" or a "liability rule."

A property rule prevents any contemplated transaetion tainted with self-dealing from proceeding without the minority owners' consent. That is, a transaction can only be performed with the consent of the disinterested group at a price that is a function of the group's subjective evaluation of its worth. This category includes systems that either deny interested parties a vote in the matter or require the approval of the disinterested majority of the minority.

A liability rule allows transactions tainted with self-dealing to be imposed on an unwilling minority but ensures that the minority is adequately compensated in objective market-value terms. This category includes systems that allow a controlling owner with a conflict of interest to vote but require that the transaction be "fair."

Classifying each solution to the self-dealing problem as either a property or liability rule provides a framework for analyzing the factors influencing the choice between the two rules. Applying the liabilityrule/property-rule framework in the context of corporate self-dealing illustrates that an understanding of adjudication and negotiation costs must inform the choice of rules governing corporate self-dealing. In turn, the sum of these costs is influenced by the efficacy of the local judicial system and market mechanisms, such as the market for corporate control, the efficiency of capital markets, and the diversity, level, and sophistication of security-holders.

Part I of this Article explains the problem of corporate self-dealing as a case in which the voting mechanism has failed. It addresses the advantages and disadvantages of the possible solutions to the self-dealing problem, including an absolute prohibition on self-dealing, the majority-of-theminority requirement, the fairness test, and nonintervention. This analysis yields two conclusions. First, corporate laws must incorporate some form of minority protection as a mandatory rule. Second, the most efficient solutions are the fairness test and the majority-of-the-minority approach.

Part II applies the liability-rule/property-rule framework to the protection of group rights in the context of corporate self-dealing. Whereas

10. See generally Guido Calabresi \& A. Douglas Melamed, Property Rules, Liability Rules, and Inalienability: One View of the Cathedral, 85 HARv. L. REv. 1089 (1972). 
fairness tests are defined as a type of liability-rule protection, the majorityof-the-minority requirement is defined as a type of property-rule protection. This distinction derives from the type of valuation (subjective versus objective) underlining the transaction and the distributive ramifications of each solution. The liability-rule/property-rule framework demonstrates that the choice between the rules controlling corporate self-dealing affects the division of the transaction's surplus between the minority and the majority. The property rule transfers most of the surplus to the minority while the liability rule passes most of the surplus to the majority.

Part III describes the different factors affecting the choice of an optimal solution. The choice's utility depends upon the total transaction costs associated with a given system, including both the negotiation costs arising from a property rule and the adjudication costs associated with a liability rule. In turn, these costs are affected by the effectiveness of the local judicial system and by market mechanisms, such as the market for corporate control, the capital market, and the type of investors active in the market. Finally, this Part provides a comparative overview and analysis of five legal systems-the United States (Delaware in particular), the United Kingdom, Canada, Germany, and Italy-to demonstrate the applicability of the theory. The analysis in this Part yields two important conclusions. First, there is no single efficient solution suitable for every country. Instead, any solution to the self-dealing problem must conform to the local conditions (the adjudication and negotiation costs) of a given jurisdiction. Second, the rules governing self-dealing transactions in Delaware, believed to be indeterminate and opaque, are shown to be efficient and coherent.

\section{I}

\section{The Problem of Self-Dealing and Possible Solutions}

\section{A. Self-Dealing and the Voting Mechanism}

Voting is commonly accepted as the best method for extracting group consensus from the disparate subjective assessments of the group's members. The voting mechanism is based on the assumption that the majority opinion expresses the "group preference," that is, the optimal choice for the group as a whole. ${ }^{11}$ Voting, however, can only be effective in formulating

11. See Shmuel Nitzan \& Uriel Procaccia, Optimal Voting Procedures for Profit Maximizing Firms, 51 PUB. CHоICE 191 (1986). In voting for or against a transaction, each member of the group subjectively assesses the merits of the proposed deal and expresses her particular informational perspective. The voting process aggregates the subjective assessments of the individuals into a single coherent stance that expresses group consensus. See Shmuel Nitzan \& Jacob Paroush, Optimal Decision Rules in Uncertain Dichotomous Choice Situations, 23 INT'L. ECoN. Rev. 289 (1982). Another approach to voting was suggested by Gilson and Black: "A majority requirement [is] based on the simple assumption that if more shareholders favor a transaction than oppose it, the gains to those favoring it will exceed the losses to those opposing it and, therefore, the transaction will result in a net gain.” Ronald J. Gilson \& Bernard S. Black, The law and Finance of Corporate 
the group's stance from the various individual positions of its members if each member's vote is based on an honest appraisal of her best interests as a member of the group ("sincere voting"). ${ }^{12}$ Whenever voters take into account how other members of the group will vote ("strategic voting") vote according to a personal interest conflicting with the interest of the group ("conflict of intercst voting" or "self-dealing"), the voting procedure ceases to function as an indicator of transactional efficiency.

This Article focuses on the self-dealing problem, which arises when the personal interests of some voters conflict with the group's interests. In a conflicted situation, voting does not necessarily express the "group preference." This problem is quite common when a transaction between the group and one of its members is slated for a vote. In such circumstances, the basis for the voter's decision will no doubt focus on her own selfinterest rather than on the transaction's value for the group as a whole. A self-dealing situation can thus neutralize the voting mechanism's ability to determine group preference. ${ }^{14}$

It does not necessarily follow, however, that all transactions bearing an element of conflicting interests are inefficient transactions. It is possible that, in certain situations, a transaction with an interested shareholder may be the best option availablc to the group. For example, a corporation seeking credit may find that, in some circumstances, a loan taken from its controlling owners is the cheapest option. ${ }^{15}$ Indeed, in some cases, an important transaction may simply be impossible without such selfdealing. ${ }^{16}$ Similarly, a self-dealer may have a competitive edge in the market, or even an advantage stemming from her proximity to the group, with the result that a deal with her is in the group's best interests.

ACQuisitions 643 ( $2 \mathrm{~d}$ ed. 1995). Another view is that the vote should express the best approximation of the choice that would be implemented if, instead of a group, a single individual were making the decision. See Lucian A. Bebchuk, The Sole Owner Standard for Takeover Policy, 17 J. Legal Stud. 197 (1988).

12. See Amartya Sen, Behavior and the Concept of Preference, in Rational Cholce 60 (Jon Elster ed., 1986).

13. The problem of strategic voting has been dealt with elsewhere. See Zohar Goshen, Controlling Strategic Voting: Property Rule or Liability Rule?, 70 S. CAL. L. Rev. 741 (1997) (analyzing the sources for strategic voting and proposing a solution).

14. See Kenneth J. Arrow, Social. Choice and Individual Values (2d ed. 1963); Duncan Black, The Theory of Committees and Elections (1958); Gilson \& BlaCk, supra note 11, at 649.

15. The rate of interest on the loan will be determined on the basis of, inter alia, the existing information about the corporation. While it may be difficult to present an accurate portrait of a corporation to an outside lender-because, among other reasons, part of the information is based upon estimates and evaluations, and a lender tends to regard the data with which she is presented with suspieion-the shareholder/lender will have better aecess to such information and a better idea of its reliability.

16. See, e.g., Case v. New York Cent. R.R., 204 N.E.2d 643 (N.Y. 1965) (holding that board of directors' decision to consolidate taxes between the parent company, which suffered losses, and its subsidiary, which registered profits, created a tax savings that was not unfair dealing). 


\section{B. Possible Solutions to Self-Dealing ${ }^{17}$}

The question of whether transactions involving conflicting interests are efficicnt or inefficient is at the root of the self-dealing problem. For this reason, an adequate solution to the problem rcquires meehanisms that can distinguish between efficient and inefficient deals. Any solution to the problem of conflict-of-interest voting should maximizc the execution of efficient deals and minimize the execution of ineffieient ones. From this perspective, this Section evaluates the range of solutions that corporate law has set forth to address the sclf-dealing problem.

\section{Prohibition on Self-Dealing}

At one end of the range is an outright prohibition on self-dealing transactions. This solution stems from a fundamentally negative view of transactions tainted by a conflict of interest. Historieally, courts have adopted this view: Any deal born of a conflict-of-interest vote was voidable and could be repudiated by the corporation, regardless of its terms or its desirability to the corporation. ${ }^{18}$ In practice, this approach is identical to a requirement of unanimous approval for transactions involving a conflict of interest. ${ }^{19} \mathrm{~A}$ requirement of unanimity eliminates the problem of conflicting interests, since the entire group must uphold the transaction. When the entire group consents, there is no risk of harm to any individual in the group.

Ostensibly, this approach "solves" the problem: Self-dealing will presumably not occur under a regime prohibiting it. ${ }^{20}$ If self-dealing is considered pernicious, an outright prohibition is a simple solution. Such a rule would be easy to apply since it obviates the need to perform complicated evaluations. And it would be effective in preventing most of the inefficient deals.

On the other hand, if our initial position is that a significant number of self-dealing transactions are efficient despite the presence of a conflict of interest, ${ }^{21}$ an outright prohibition will exact too heavy a price-the loss of too many efficient transactions. A requirement of unanimity would

17. In this Article I focus on self-dealing transactions and the rules concerning them at the shareholder level, as opposed to the board-of-directors level. Thus, the discussion is confined to the tensions inherent in shareholder vote concerning self-dealing transactions. For an analysis relating to the board of directors, see Luca Enriques, The Law on Company Directors' Self-Dealing: A Comparative Analysis, 2 INT'L \& CoMP. CoRP. L.J. 297 (2000).

18. See Marsh, supra note 6.

19. Historically, fundamental changes in the corporation-e.g., dissolutions, mergers, changes in financial structure or corporate charter-required unanimous consent. See Joseph E. Calio, New Appraisals of Old Problems: Reflections on the Delaware Appraisal Proceeding, 32 AM. Bus. L.J. I, 7 nn.25-31 (1994).

20. Of course, since discovery and enforcement are never perfect, some self-dealing will occur, just as prohibiting acts of theft does not eliminate them.

21. See supra text accompanying notes 15-16. 
frustrate many transactions that would benefit the corporation and would maximize the risk of error $^{22}$ and holding out. ${ }^{23} \mathrm{~A}$ single negative vote would suffice to foil the transaction, regardless of whether opposition is the result of strategic holding out or a bona fide mistake as to the merits of the deal. From this perspective, an outright prohibition or a requirement of unanimity is irreconcilable with the goal of preserving the performance of efficient transactions and is therefore too extreme to serve as a general solution to the problem.

\section{The Majority-of-the-Minority Vote}

Rather than completely prohibiting self-dealing transactions, the majority-of-the-minority solution uses the voting mechanism to determine the group's consent by excluding those shareholders with a conflict of interest from participating in the vote. This solution assumes that only the votes of the disinterested members of the group are relevant to determine the "group preference." If the remaining participants in the ballot (the minority) form a large group, it is reasonably assumed that the vote does, in fact, reflect the group preference.

This ban on conflict-of-interest voting has two primary benefits. First, it prevents a self-dealer from imposing a transaction on an unwilling minority. Second, since such an approach is based upon consent, it is unnecessary to bring the transaction before the courts for an objective evaluation.

Placing the decision making in the hands of the minority might, however, preclude efficient transactions in certain situations. For example, when the minority is composed of a small group, the threat of strategic voting increases. ${ }^{24}$ Since the interested majority obviously will support the transaction, the minority, or some of its members, can attempt to hold out for a larger piece of the transaction's expected profit. So long as the extorted sum leaves the majority with some amount of profit, the transaction may still be performed. But if the minority, or some of its members, pushes the holding-out attempt too far, an efficient transaction may be lost. Likewise, even a "reasonable" hold out will preclude a transaction if the interested majority refuses to concede to the opposing minority's demands for strategic reasons such as guarding its reputation.

22. The greater the support a decision enjoys among the voters, the greater the probability that this choice will be an efficicnt transaction for the group. However, this increased probability of reaching an efficient decision has its price: Deals that enjoy the support of a regular majority but nonethcless fail to reach the unanimity threshold will be rejected. The unanimity requirement, therefore, increases the risk of error by increasing the minority's influence over the outcome.

23. Holding out is one form of strategic voting in which a voter who believes a transaction to be worthwhile nonetheless chooses to oppose it in an attempt to extract greater personal gains in exchange for her consent. See Goshen, supra note 13.

24. See id. 


\section{The Fairness Test}

Another approach permits the self-dealer to vote but provides that these transactions will subsequently be examined by an independent body, typically the courts, on an objective-valuation basis to determine if they meet certain standards imposed by law. The most relevant standard for our purposes is the fairness test.

Under the fairness test, the courts make a substantive evaluation of the transaction at issue. ${ }^{25}$ Suppose, for example, that a controlling shareholder has sold the company an asset for $\$ 100$ and that the transaction is upheld. A minority shareholder can claim that the transaction violated the fairness test. A court asked to rule over this claim will have to determine objectively whether the asset is indeed worth $\$ 100$, perhaps by appointing an independent appraiser to make such a determination. Under the fairness test, the court evaluates the terms of the transaction in comparison to market parameters. ${ }^{26}$

Essentially, a solution that holds a transaction to the fairness standard allows the person with a conflict of interest to effect a "taking," that is, to impose the transaction on the minority, but it likewise enables the minority to claim before the courts that the transaction is unfair. ${ }^{27}$ It is important to note, however, that the fairness test does not insure that the minority gets the best attainable deal. The fairness-test protection is no more than a guarantee that the transaction will be fair ${ }^{28}$ and that the minority will gain some portion of the profit reaped by the transaction on terms similar to those that might be expected of a transaction between willing buyers and sellers. The use of an objective measuring standard leaves no place for unique characteristics or special assessments of value that might affect the value the parties themselves aetually ascribe to the assets. ${ }^{29}$

Furthermore, a determination of the "objective" value of an asset is not an exact science since the court must base its decision on value assessments made by professionals. These assessments are influenced by assumptions that reflect the subjective viewpoint of the appraiser, including assumptions about whether certain future events will occur and their likely effect. Moreover, these assessments are subject to tendentiousness; specifically, a rendered opinion is liable to be slanted to meet the demands of the

25. For cases in which courts make such an evaluation, see supra note 2 .

26. See, e.g., Robert Charles Clark, Corporate Law 166 (1986).

27. The duty of loyalty has a similar effect. See, e.g., Zahn v. Transamerica Corp., 162 F.2d 36 (3d Cir. 1947). By imposing a duty of loyalty, the law rcquires the majority to exercisc its discretion in good faith for the benefit of the group as a whole. Determining whether the duty was violated in a conflict-of-interest deal will require an objcctive evaluation of the deal.

28. See infra note 59 and accompanying text.

29. Compare Alan Schwartz, The Fairness of Tender Offer Prices in Utilitarian Theory, $17 \mathrm{~J}$. LEGAL STUD. 165 (1988) (advocating objective market valuations), with Bebchuk, supra note 11 (advocating subjective consensual valuations). 
party who has commissioned it. This slant often favors the party interested in seeing the transaction performed. ${ }^{30}$ In addition, the court is compelled to decide between the inevitably differing opinions that are tendered by the opposing parties in order to fix the "correct" value of the transaction. ${ }^{31}$ Yet, despite the drawbacks of a system that relies on the courts and professional assessments of value, there is no other means of determining the objective value of an asset. What is clear is that the transition from voluntary transactions, which reflect subjective value, to objective market-value transactions, which the majority can impose on the minority, inevitably introduces an element of uncertainty as to valuation.

\section{Nonintervention}

At the opposite end of the range from a total prohibition against selfdealing transactions is the no-action option, which leaves the problem to the unconstrained forces of the market to resolve. In its favor, it might be argued that nonintervention allows market forces to generate appropriate solutions to self-dealing situations on an individual basis. This approach, it has been claimed, is more efficient than working backward from a general, law-imposed solution. ${ }^{32}$

To illustrate the operation of a nonintervention approach, suppose that no corporation in the market employs a protection against conflict-ofinterest voting. Under this scenario, investors considering whether to join a corporate group as shareholders would be aware that self-dealing might threaten their investment. ${ }^{33}$ Thus, unless certain protections were voluntarily introduced to prevent the risk of complete loss, securities would be rendered worthless, and investors would simply opt out of the securities market altogether. The market, however, would respond by providing such protections. For example, a corporation that is not interested in stripping the investors of their investment would include explicit protection-based

30. See Lucian A. Bebchuk \& Marcel Kahan, Fairness Opinions: How Fair Are They and What Can Be Done About It?, 1989 DuKE L.J. 27, 37-46 (suggesting that investment banks have an incentive to write fairness opinions consistent with managerial desires because of the fee structure under which banks are eompensated).

31. See, e.g., Gonsalves v. Straight Arrow Publishers, Inc., 701 A.2d 357 (Del. 1997) (reversing a ehancery court decision, in with the lower court strategically chose one valuation over the other-rather than determining a mid-way valuation-in settling a battle of experts who presented enormously differing valuations, as a way to encourage valuations to be closer to the true value); In re Shell Oil Co., 607 A.2d 1213, 1222 (Del. 1992) (recognizing the difficulties raised by the battle of experts in appraisal proceedings and recommending that the Delaware Court of Chancery appoint its own expert witness in appropriate cases); Kahn v. Household Acquisition Corp., 591 A.2d 166, I75 (Del. 1991) (recognizing that a dispute over value is a battle of experts).

32. See, e.g., Frank H. Easterbrook \& Daniel R. Fischel, Corporate Control Transactions, 91 YALE L.J. 698 (1982) (arguing that legal rules should imitate what the parties would bargain for in the absence of negotiation costs and that fiduciary principles can be used to approximate the bargain).

33. A perfect market model assumes that the market incorporates all agency costs (in this case, the risk of expropriation) in the price of the security. See Jensen \& Meckling, supra note 1. 
either on a fairness test or on a majority-of-the-minority requirement-as a term of the contract by which the security is offered to the public. The investors, for their part, would be willing to pay an appropriate price for a security that included such protection and little or nothing for one that did not. $^{34}$

Indeed, in a perfectly efficient market (one without transaction costs), the prices of securities will reflect the value of the different defenses they carry. Within such a market, each corporation can provide its securities with the protection most appropriate for its needs, and each investor can choose the type of protection she requires. Nonintervention, therefore, would prove to be an effective solution in a pcrfectly efficient market. ${ }^{35}$

In reality, however, markets are not perfect, and the efficiency level of a capital market is a function of the economic and lcgal conditions in a given jurisdiction. If a market is not sufficiently efficient to accurately price the different securities, nonintervention will fail as an effective solution. This failure is due, in large part, to information costs. Under the nonintervention scenario, for an investor to properly price a security, she must ascertain the effectiveness of the protection offered by the security as well as evaluate the procedural limits that will prevent the eventual cancellation of that defense ${ }^{36}$ Only through a process of gathering and evaluating all the relevant information can the investor price the security, and she must repeat the process for each security she wants to purchase. An investor wishing to diversify her investment portfolio in such a market would encounter such prohibitively high information costs as to render the investment pointless.

Rather than gathering and evaluating specific information about each security, the investor may instead choose to estimate the probability of any corporation providing protection against self-dcaling. The price the investor would be willing to pay for any security would then represent some average based on the investor's probability estimate. This approach may generate a free-rider problem: Companies offering no protection to shareholders would derive undeserved premiums, while companies offering a protection more valuable than the average would not receive proper recompense. The companies in the latter group would have an incentive to cancel the protection while still profiting from the average premium. Of course, if this result occurred, the investor would respond by adjusting her estimation and lowering the premium she is willing to pay. Companies whose protection is worth more than the adjusted average premium would

34. See Easterbrook \& Fischel, supra note 32, at 715.

35. See, e.g., Frank H. Easterbrook \& Daniel R. Fisehel, The Corporate Contract, 89 Colum. L. Rev. 1416 (1989); Daniel R. Fischel, The Corporate Governance Movement, 35 VAND. L. Rev. 1259 (1982).

36. See Jeffrey N. Gordon, The Mandatory Structure of Corporate Law, 89 Colum. L. Rev. 1549 (1989) (analyzing the conditions justifying mandatory rules in corporate law). 
thus, once again, be driven to cancel the defense. This dynamic would be repeated until the cycle of diminishing standards reaches the no-defense point. $^{37}$

Consequently, corporations, knowing that investors are not prepared to bear information costs, may invest in publicizing the attributes of the protections they offer. In other words, the companies would internalize the costs of keeping the investors informed. The investors, nonetheless, would be required to process and evaluate the information given to them. Assuming that the corporations offered a wide variety of protections, the amount of information that potential investors would receive would still be large and their information costs would still be considerable. Again, because of market inefficiencies, we arrive at an inefficient solution. ${ }^{38}$

If all corporations could agree upon a standard protection to offer investors, the information costs would be saved. Yet corporations cannot reach such a consensus because of, inter alia, antitrust restrictions, prohibitive negotiation costs resulting from the sheer number of corporations involved, and the potential for opportunism by new corporations entering the market who refuse to comply with the consensus.

In sum, the legal imposition of a standard mandatory protection, short of a prohibition on self-dealing, is more efficient than nonintervention. ${ }^{39}$ It

37. For discussion of this phenomenon, known as the "market for lemons," see George A. Akerlof, The Market for "Lemons": Qualitative Uncertainty and the Market Mechanism, 84 Q.J. EcoN. 488 (1970); Hayne E. Leland, Quacks, Lemons and Licensing: A Theory of Minimum Quality Standards, 87 J. PoL. ECON. 1328 (1979).

38. It might he argued that nonintervention would be efficient because the market structure would change to become efficient in order to allow investments. Indeed, it is possible that investors would avoid direct investment in corporations by employing intermediaries (e.g., mutual funds) that can process information more efficiently. In this case, the market would change towards concentrated investments made by a few strong and professional institutions. Such a market would be more efficient from an informational standpoint, and nonintervention would then be a viable solution. Under this scenario, however, the market would transform from the model of the dispersed U.S. capital market into one resembling the more concentrated German market. This analysis raises the question of what form of market is appropriate in a given country. This question cannot be determined solely on the basis of conflict-of-interest considerations. Thus, for the purposes of our discussion, the dispersed U.S. market structure must be assumed as given. See Rafael La Porta et al., Legal Determinants of External Finance, $52 \mathrm{~J}$. FiN. 1131 (1997) (discussing the effect the legal environment has on the size and breadth of capital markets by comparing legal rules across countries). There is, in addition, a possible "mercury effect," wherein the problem is not solved but simply displaced to another part of the system. A transfer to a concentrated market will replace one agency problem-between the shareholders and the companies in which they invest-with another-between the public (holding shares in the mutual fund) and the intermediaries (managing the mutual fund). The information problem will be resolved between the companies and the intermediaries only to be replaced by an information problem between the intermediaries and the public. For this reason, it will again be necessary to solve the conflict-of-interest problem.

39. See Gordon, supra note 36 (providing justifications for mandatory rules). The conclusion that nonintervention is inefficient in imperfect markets is supported by empirical findings. A study of 49 countries has shown that countries with poorer investor protections, measured in terms of both the character of legal rules and the quality of law enforcement, have smaller and narrower capital markets. Moreover, the results of this study support the proposition that in legal systems which provide 
should apply to all corporations without any possibility of future cancellation. As a result, information costs will be saved by both investors and corporations. ${ }^{40}$ Moreover, the existence of a single protection establishes greater legal certainty since the courts will generate many precedents regarding the interpretation of the particular protection. ${ }^{41}$

In sum, although the self-dealing problem may be approached in a variety of ways, the most efficient solutions are the fairness test and the majority-of-the-minority rule.

The next challenge is determining which of these two options is preferable. Choosing the appropriate mandatory protection depends, as will be shown next, upon the level of market efficiency. However, imperfection in a market is a question of degree and is influenced by such factors as the prevalence of institutional investors in the market and the receptiveness of investors towards corporate information. When the level of efficiency is high (because, for example, professional investors form a strong presence and there is a rapid flow of credible information), a rule that leaves the parties with some freedom to adjust the mandatory protection is desirable. Of the two protections, the fairness test is more flexible because it avoids the costs associated with calling a shareholders meeting on every self-dealing transaction, ${ }^{42}$ while resorting to court intervention only in times of disagreement. The fairness test provides the parties with the benefits of informal negotiations "in the shadow" of the rule ${ }^{43}$ rather than forcing them to the formal vote required by the majority-of-the-minority rule in every selfdealing transaction. Since a fairness-test type of protection is more flexible, and most likely to be adopted by most corporations in an efficient market, it is more appropriate as the default mandatory protection. If they so wish, the parties can increase the level of protection and stipulate that the consent of a majority of the minority must be achieved. Part II will concentrate on these two preferred solutions and their basic characteristics.

ineffective enforcement of contracts, it is difficult to contract around inefficient legal arrangements and impossible to signal commitments for fair dealings to the market. See La Porta et al., supra note 38.

40. See Michael Klausner, Corporations, Corporate Law, and Networks of Contracts, 81 VA. L. REv. 757 (1995) (discussing the tendency of market forces to respond to the presenee of network externalities by developing a high degree of uniformity); Roberta Romano, Answering the Wrong Question: The Tenuous Case for Mandatory Corporate Laws, 89 Colum. L. Rev. 1599, 1603 (1989) (arguing that while positive claims and normative prescriptions for mandatory corporate law rules are doubtful, there is a role for mandatory corporate law when externalities are present).

41. See Kenneth B. Davis, Jr., Judicial Review of Fiduciary Decisionmaking: Some Theoretical Perspectives, 80 Nw. U. L. Rev. 1, 22 (1985).

42. As to these costs, see infra Part ll1.A.

43. See infra text accompanying note 64 . 
II

\section{Characteristics of the Preferred Solutions}

\section{A. Property Rules Versus Liability Rules}

Applying the distinction between liability rules and property rules to the solutions for self-dealing ${ }^{44}$ provides a deeper understanding of their effects. A liability rule is a legal rule that allows a transaction to be forced upon a party, provided that objectively fair compensation is made..$^{45} \mathrm{~A}$ property rule, on the other hand, precludes the carrying out of any transaction to which the owner of an asset has not consented. ${ }^{46}$

The fairness-test solution to self-dealing is best understood as a liability rule, and the majority-of-the-minority solution is best understood as a property rule. This categorization is based both on the type of valuation that characterizes each rule and on the ramifications of its distributive effect. Under the fairness test, the majority can force the transaction on the minority, subject to the payment of an objectively determined fair price. Under the majority-of-the-minority rule, the majority must obtain the consent of the minority, which will be provided based on the minority's subjective valuation. Consequently, each rule utilizes a different form of valuation and has a different effect on the division of the surplus stemming out of a self-dealing transaction. While the fairness test employs an objective valuation and leaves most of the surplus in the hands of the majority, the majority-of-the-minority rule employs a subjective valuation and enables the minority to capture a greater part of the surplus. Below I analyze the two rules as defined by these two elements: "subjective versus objective valuation" and the "division of the surplus."

This analysis assumes that self-dealing rules can be clearly categorized as either property or liability rules based on their statutory or doctrinal definitions. However, there are several other factors that warrant attention because they affect the operation of the rules. The characterization as either a liability rule or a property rule ultimately depends on the remedies provided by the courts when the rule is violated. In this respect, two issues are critical: access to the courts and the type of enforcement.

Once an existing rule is violated, the injured shareholder should have a right to access the court and ask for a remedy. Mechanisms such as derivative suits or class actions with appropriate incentives to use them must exist in order to facilitate access to courts. ${ }^{47} \mathrm{~A}$ rule "on the books," without any possibility of access to the courts, is ineffective. Consequently, a regime where the courts are inaccessible should be regarded as a system of

44. See Calabresi \& Melamed, supra note 10.

45. Id. at 1092 .

46. Id.

47. See John C. Coffee, Jr., The Unfaithful Champion: The Plaintiff as Monitor in Shareholder Litigation, 48 LAw \& ConTemP. Probs. 5 (1985). 
nonintervention. ${ }^{48}$ However, access can be provided in different degrees. One legal system might allow any shareholder to bring a derivative suit, while other systems might restrict this right to shareholders holding $5 \%$ or $10 \%$ of the shares. ${ }^{49}$ Access can also be denied indirectly through curtailing incentives and imposing high risks and costs on those attempting to enter the court. Therefore, the degree of access to the courts will determine whether a system is providing any meaningful protection that can be treated as either a property rule or a liability rule, or whether a system should be regarded as adopting a nonintervention approach.

Once a rule is "on the books" and injured parties have access to the courts, the type of enforcement provided by the court is crucial. A system could have a property-rule protection on the books, but a liability-rule protection in praetice, or vice versa. A brief example will illustrate this point. Suppose that the law of a particular country requires majority-of-theminority approval for a self-dealing transaction. This requirement suggests that this country has adopted a property-rule protection "on the books." Now suppose that the interested majority shareholder does not refrain from voting and accordingly causcs the corporation to approve the self-dealing transaction. If a court facing such a claim does not invalidate the transaction but merely looks to the fairness of the transaction, then it becomes evident that the law of that country is better characterized as a liability rule rather than a property rule. ${ }^{50}$

Whether the law as stated "on the books" is in effect the actual approach of the law in any given jurisdiction depends on the quality of the courts' interpretation and the efficacy of their implementation of the law. If courts refuse or are unable to enforce the law as it is stated in the statutes, then the law will be different from that envisioned by the legislators. ${ }^{51}$

In sum, access to court and enforcement are factors in determining a rule's classification. While access to court is primarily controlled by the

48. Indeed, there are countries in which the legal rights are not coupled with effective access to courts. See La Porta et al., supra note 38; La Porta et al., infra note 67.

49. For the limitations presented by the Italian law to derivative suits, see, for example, infra note 162.

50. See, e.g., Luca Enriques, Off the Books, But on the Record: Evidence from Italy on the Relevance of Judges to the Quality of Corporate Law, in Global MARKETS AND Domestic Institutions: Corporate LaW and Governance in a New Era of Cross Border Deals (Curtis Mihaupt ed., forthcoming 2003). Enriques notes:

[W]hile Article 2391 of the Italian Civil Code apparently requires company directors to remove themselves from decisions involving self-interested transactions, according to the construction that has prevailed in the courts (and among legal scholars) it only imposes a duty of faimess upon the director when deciding upon the transaction (either in the boardroom, when a vote by the board is required, or when directly acting on behalf of the corporation). Id.

51. See id. (analyzing the relationship between the law as it is stated "on the books" and how it is enforced by the courts, and exploring the possibility of a country having a "bad" corporate law on the books but still having a "good" corporate law off the books as a result of having a qualified and efficient judiciary). 
quality of the law, the type of enforcement is primarily controlled by the quality of the judiciary system. In the following analysis, I assume a system that provides access to courts and enforcement sufficient to enable clear characterization of the rules as either property or liability rules.

\section{B. Subjective Versus Objective Valuations}

A property rule can be distinguished from a liability rule by the manner in which the parties value a transaction. That is, in a market economy, voluntary transactions are based upon mutual consent and manifest the subjective conclusion of each of the partics that the transaction is worthwhile. On the other hand, involuntary transactions, such as expropriations, are nonconsensual and therefore require an objective valuation to determine the appropriate "price" (compensation) for such a transaction.

A solution based on the fairness rule assumes that, once conflict-ofinterest voting is permitted, the majority can force a transaction upon the minority. The protection afforded to the minority ensures only that a fair price is obtained, which is determined by evaluating the objective value of the transaction. ${ }^{52}$ The faimess rule establishes a regime of involuntary transactions, and, thus, replaces subjective valuations of the contending groups of shareholders with an objective measure.

If the power to determine whether or not a transaction will be approved is given to the minority, the majority is unable to force a deal upon the minority. Thus, a transaction will only transpire if the minority, or more precisely, a majority of the minority, has consented to it. This arrangcment assures the minority more than a minimum fair price, howevcr. It empowers the minority to look after its own interests and to strive to obtain the maximum price it can achieve. Placing the decision in the minority's hands maintains a regime of voluntary transactions and preserves the role of subjective valuations. $^{53}$

52. There is a difference in the application of the fairness test in appraisal proceedings and in other transactions involving self-dealing. In appraisal proceedings, in which shareholders who opposed a merger ask the court to evaluate whether the price offered in the merger was fair, the merger is complete; the court is only determining the appropriate compensation for the shareholders who objected to the merger. In other transactions involving self-dealing, the court might pass judgment on the fairness of the deal before its performance. However, the majority can offer the price that the court determined to be objectively fair and complete the deal despite the minority's objection. Either way, the measure of the fairness is based on objective evaluation, and it makes no difference whether the valuation process takes place before or after the deal is completed. In practice, however, it is extremely diffieult to receive a preliminary injunction and have the court review the deal before it is completed. See, e.g., In re Trans World Airlines, Inc. S'holders Litig., No. 9844, 1988 Del. Ch. LEXIS 139 (Del. Ch. Oct. 21,1998 ) (refusing to enjoin a merger on the ground that the minority shareholders had available an effective legal remedy by way of an action for rescissionary damages and that an injunction might result in irreparable harm).

53. Minority protections can afford protection to either individuals in the minority group or to minority members as a group. A property rule conditioning a self-dealing transaction on the consent of the majority of the minority protects the minority as a group, while a dissenting minority (of the 


\section{The Division of the Surplus}

A property rule can also be distinguished from a liability rule by the effect that each rule has on the division of the surplus stemming from the self-dealing transaction. Before presenting the effect of the rules in the corporate self-dealing context, it will be helpful first to present the general case. A voluntary transaction between individuals generates a surplus, as a result of the differcnce in subjective values the parties attach to the deal. The difference between the valuations of a buyer and a seller represents the surplus from the transaction. To illustrate, if Andy values an asset at $\$ 100$, while the same asset is worth $\$ 200$ to Bonnie, the $\$ 100$ spread between their valuations would constitute a surplus. Any actual price that the parties might strike between $\$ 100$ and $\$ 200$ would thus be an efficient transaction.

If the asset has a market price that is located within the range of possible prices, the parties will effect the transaction at the market value. Andy will refuse to sell the asset to Bonnie for less than the market price, and Bonnie will refuse to purchase it for more than the market price, since either side can perform an alternative transaction in the open market at the market price. The forces of supply and demand will determine the division of the surplus between the parties.

On the other hand, when an asset has no market price, ${ }^{54}$ the division of the surplus will be subject to negotiation, and the outcome will depend upon external factors, such as the negotiating skills and bargaining power of each party. ${ }^{55}$ If the price is set at $\$ 101$, Andy receives $\$ 1$ and Bonnie $\$ 99$ of the surplus, whereas if the priee is $\$ 199$, the division of the $\$ 100$ surplus will be reversed between Andy and Bonnie. In either instance, the transaction will be an efficient transaction and will be "fair" in the sense

minority) voter will be coerced to aceept the majority view. On the other hand, a property rule conditioning a self-dealing transaction upon the unanimous consent of all voters protects each and every member of the minority on an individual basis, such that no voter can be coerced.

Similarly, a liability rule ean provide protection either on an individual or a group basis. An appraisal right, for instance, provides liability-rule protection on an individual basis by aseertaining the objective premerger corporate value. Only sharcholders who opposed the merger, gave notice, and tendered their shares are eligible for the appraisal right. See Hideki Kanda \& Saul Levmore, The Appraisal Remedy and the Goals of Corporate Law, 32 UCLA L. Rev. 429 (1985). Even if such a shareholder prevails, there are no effects on other shareholders who voted in favor of the merger and, thus, received lower prices. On the other hand, the liability-rule protection of fiduciary duties and the "entire fairness" standard are granted on a group basis. It is sufficient that one shareholder win the case, either through a class action or a derivative suit, for the other members of the group to be entitled to a similar compensation, regardless of their ex ante position on the quality of the transaction. See GiLson \& BLACK, supra note 11, at 1266-69 (analyzing the different effects of each rule on the corporation and its shareholders).

54. 1 use the term "market price" rather than the term "market value" because it is only very rarely that a transaction involving self-dealing will not have a "market alternative" that can provide us with a market price.

55. See, e.g., Robert Cooter, The Cost of Coase, 11 J. LEGAL Stud. 1 (1982). 
that it will be effected with mutual consent and, as such, will be upheld by the courts.

When the asset is protected by a property rule, the buyer has no means of compelling its purchase. The seller can negotiate freely in an attempt to secure a larger share of the surplus. Her success in seeing the deal performed will depend on her negotiating skills and whether alternatives exist which may substitute for the asset. The fewer alternatives there are, the larger the slice that the seller can expect out of the surplus. Conversely, where the asset is protected by a liability rule, the purchaser need not enter into negotiations at all; she can simply take the asset by offering a price that is objectively fair.

What is a "fair" price? If the court's test is based on the price set between a willing seller and a willing buyer, then a fair price will mean the price generated by any efficient transaction, that is, any price between $\$ 101$ and $\$ 199$ in Andy and Bonnie's case. ${ }^{56}$ Accordingly, it may be assumed that the purchaser will offer a price closer to $\$ 101$ than to $\$ 199$ because under a liability rule the purchaser will endeavor to set a price by which most of the surplus will vest with her. ${ }^{57}$

This analysis holds in the corporate self-dealing context as well. The two solutions to the self-dealing problem will have different effects on the division of the surplus between the parties. In this respect, a property rule and a liability rule differ on two dimensions: the direct division of a given transaction's surplus and the frequency of the self-dealing transactions.

\section{The Direct Surplus Division}

The liability-rule approach gives an advantage to the majority, while the property-rule approach gives the minority more bargaining power. ${ }^{58}$ Suppose that a group of voting shareholders has an asset that it values at $\$ 100$, and the majority group is interested in purchasing the asset since it values the asset at $\$ 200$. In a regime built on the fairness doctrine, the majority can force the transaction upon the minority, contingent upon its obligation to ensure a fair price. The majority can offer a price in the lower range of possible surplus values, such as $\$ 101$, and still live up to the

56. See, e.g., Melvin A. Eisenberg, Self-Interested Transactions in Corporate Law, 13 J. CoRP. L. 997,999 (1988).

57. In reality, a court, as well, will be influenced by equity considerations with regard to the division of surplus value. See Charles M. Yablon, On the Allocation of Burdens of Proof in Corporate Law: An Essay on Fairness and Fuzzy Sets, 13 Cardozo L. Rev, 497, 512 (1991) (noting that by using terms such as "entire fairness," "intrinsic faimess," or "the most scrupulous inherent faimess," rather than "simple faimess," courts are actually demanding that a substantial part of the surplus be shifted to the minority). However, here too, the price that will be set can be expected to be on the lower side of the range of possibilities.

58. See David D. Haddock et al,, Property Rights in Assets and Resistance to Tender Offers, 73 VA. L. Rev. 701, 707 (1987); Susan Rose-Ackerman, I'd Rather Be Liable Than You: A Note on Property Rules and Liability Rules, 6 INT'L REv. L. \& ECON. 255 (1986). 
fairness standard. As long as the actual price falls between $\$ 100$ and $\$ 200$, the minority will have sustained no actionable wrong. Since the same transaction could potentially take place even under the regime of strictly voluntary transactions, it cannot be deemed unfair. ${ }^{59}$ The mere fact that the surplus has been divided inequitably does not demonstrate per se that the transaction is unfair. ${ }^{60}$

A property rule that requires the minority's approval for a transaction in which a conflict of interests arises empowers the minority to demand a larger portion of the surplus (in the last example \$199) than it would receive under the liability rule. Yet, abusive holding out by the minority may also lead to the loss of worthwhile transactions. Thus, in the above example, suppose that the majority offers a price of $\$ 180$ and the minority demands $\$ 201$. This seemingly irrational demand is conceivable since the minority would have no way of knowing precisely what value the asset has for the majority and may mistakenly demand too much. In this case, the majority would not proceed with the transaction and the minority will retain an asset worth $\$ 100$ (by its own assessment) instead of the $\$ 180$ which it might have received. An efficient transaction will thus have been foiled.

\section{The Frequency of Transactions}

Under a property rule, the majority knows beforehand that the minority can, by demanding a high price, extort a sizeable portion of the surplus of any proposed transaction initiated by the majority. ${ }^{61}$ Therefore, the majority will refrain from initiating transactions with the minority and seek

59. See, e.g., ReviSED MOdel Bus. CORP. ACr $\$ 8.61$ (1989) (note on fair transactions). Section 8.61 provides:

It has long been settled that a "fair" price is any price in that broad range which an unrelated party might have been willing to pay or willing to accept, as the case may be, for the property, following a normal arm's-length business negotiation, in the light of knowledge that would have been reasonably acquired in the course of such negotiations, any result within that range being "fair."

Id.

60. The most obvious example is the rule that, in a merger, the "appraisal right" given to the shareholders does not include the profits from the merger itself. A merger allows the majority to squeeze out the minority in exchange for the price fixed by the majority in the merger (a self-dealing transaction). The minority opposing the merger may demand the right to an independent appraisal, by which it will be determined if the merger price is fair. That is, the defense is based on a liability rule. The surplus from the transaction includes the profits that may be generated from the merger itself. Since the minority had ownership of a company whose merger allowed the majority to receive the profits of the merger, it might be thought that the minority should be entitled to some portion of the merger profits. But this is not the case. The rule is that in evaluating whether the price is fair, merger profits are not taken into account. In other words, the opposing minority is given no portion of the surplus. See Benjamin Hermalin \& Alan Schwartz, Buyouts in Large Companies, 25 J. Legal Stud. 351 (1996). See also Case v. New York Cent. R.R., 204 N.E.2d 643 (N.Y. 1965) (discussing a situation in which the consolidation of taxes between the parent company, which suffered losses, and its subsidiary, which registered profits, created a tax saving, of which the vast part was enjoyed by the parent).

61. See Hermalin \& Schwartz, supra note 60. 
out less extortive alternatives. Only when the minority possesses a unique asset will the majority be forced to address the minority's excessive demands, and even in such circumstances, some such transactions will fail to take place because of holding-out attempts. The transfer of the decision power to the minority enhances the minority's ability to demand a larger share of the surplus in those transactions that are performed but reduces the total number of transactions involving the minority that will in fact be performcd.

The fairness test, on the other hand, does not guarantee the minority a large portion of the surplus, but it does guarantee that efficient transactions are carried out. The majority is not deterred by holding out and can push through any transaction it wishes, provided always that the minority receives a fair price. The fairness test thus reduces the minority's profit on each transaction but ensures the maximum number of transactions.

However, just as the transfer of the decision-making power to the minority carries an inherent risk that extortionary demands will doom efficient transactions, the fairness-test approach transfers power to the courts, which may erroneously ratify inefficient transactions or ban efficient ones. To illustrate, in the above example, an inefficient transaction would occur if the majority proposed a price of $\$ 95$, and the courts approved the deal, overriding the minority's objections based on a (faulty) objective assessment of the price. In sum, the distinction between property rules and liability rules, given the different valuation methods (subjective versus objective) and the different effects on the division of the surplus, applies to the rules regulating self-dealing.

\section{III}

\section{Factors Determining the Right Solution}

Which of the alternatives discussed above is the preferred solution? In other words, is there "one efficient rule"? Having classified the fairness test as a liability rule and the majority-of-the-minority rule as a property rule, this question can be approached as a choice between a liability rule and a property rule. The analysis will proceed in three steps. First, the negotiation costs attendant upon a property rule and the adjudication costs associated with a liability rule will be analyzed. Second, the market mechanisms affecting the relative weight of the negotiation and adjudication costs will be explored. Finally, I argue that the question of which is the preferable rule cannot be answered purely in the abstract. Indeed, once all relevant costs are considered, the answer depends upon a number of empirical factors which include: the existing arrangements in the legal system, the efficiency and expertise of the courts, the quality and sophistication of market mechanisms and institutions, and the influence of certain cultural norms on the business world. 
According to Coase's theorem, in a world without transaction costs it makes no difference which rule is adopted: In either case efficient transactions will be performed. ${ }^{62}$ Where transaction costs are incurred, however, the choice between a liability rule and a property rule depends upon which rule better ensures the realization of efficient transactions and the avoidance of inefficient ones. Although negotiation costs are primarily responsible for the failure to bring about efficient transactions, they might still be preferable to adjudication costs. The failure of negotiations can result from a variety of factors, each with its particular influence on the efficacy of the rule adopted. Upon examination one might, however, conclude that, despite its failures, a property rule is still a more desirable solution than a liability rule with its attendant adjudication costs. For instance, there may be cases in which it may be more desirable to bear the hazards of holdouts than to refer the decision to an inefficient or corrupt court system. ${ }^{63}$ Hence, the effect of the differing rules must be tested by focusing on the relative costs that arise in real-world situations.

\section{A. Negotiation Costs}

Although both types of rules involve negotiation costs, these costs are much steeper under a property-rule system. A liability rule measures a selfdealing transaction on an objective nonconsensual basis, and as such, does not primarily require negotiation. However, the parties can negotiate "in the shadow" of the liability rule to avoid legal intervention. ${ }^{64}$ Such negotiations enjoy the benefits and costs of being informal. The costs of these negotiations depend on the presence of sophisticated investors and the effectiveness of the judicial system. The more effective and precise the courts, the easier it is for sophisticated investors to anticipate courts' rulings and to avoid any need for actual recourse to them.

A property rule, which transfers the decision as to the validity of a self-dealing transaction into the hands of the minority, also involves negotiations between the majority and the minority. ${ }^{65}$ But, unlike the

62. See Ronald H. Coase, The Problem of Social Cost, 3 J.L. \& Econ. I (1960). The chosen rule will affect the division of surplus among the parties involved but not the performance of the transaction.

63. Such was the case at a certain time in Russia. See Bernard Black \& Reinier Kraakman, $A$ Self-Enforcing Model of Corporate Law, 109 HARv. L. REv. 1911 (1996) (developing a "selfenforcing" model for drafting corporate law for emerging capitalist economies).

64. See lan Ayres \& Eric Talley, Solomonic Bargaining: Dividing a Legal Entitlement to Facilitate Coasean Trade, 104 YALE L.J. 1027 (1995).

65. An important difference between the application of the liability-rule/property-rule framework to cases of individual's and group's rights should be noted: While a property rule concerning an individual's rights allows for direct negotiations, negotiations with the minority take the different and more complicated form of voting. Sometimes the negotiation involves voting on a "take it or leave it" basis. Sometimes it involves informal discussions betwcen some institutional shareholders and the company before an offer is put to a vote. And, sometimes, preliminary negotiations take place through a committee of the board of directors appointed for this purpose. In any case, the important feature of 
liability-rule scenario, the costs of this type of negotiations can be considerable. First, there are administrative costs, which include dispatching notices of an impending ballot and providing all the voting shareholders with background information on the transaction, each of whom returns a proxy form indicating her vote. However, such costs certainly do not prevent negotiation from taking place, ${ }^{66}$ and, indeed, for shareholders, such an arrangement is routine. ${ }^{67}$

Second, the voting process requires that the voters study the material, adopt a position, and vote. This process can be expensive for the voters, and often many will refrain from voting or will blindly support management's position. The nonparticipation of some voters will detract from the quality of the decision making. ${ }^{68}$ A minority's blind support of management, which is generally interested in the transaction, thwarts the purpose of having the matter voted on by the disinterested minority. Where institutional investors are involved in the ownership of a corporation, the participation of informed and able investors in the decision-making process improves the quality of the decision making. ${ }^{69}$ Unfortunately, however, at times these investors act, directly or indirectly, in collusion with management or the controlling owner against the remaining shareholders. ${ }^{70}$

the group situation is that in the end, nothing compels a voter to accept an offer she deems inappropriate.

66. Even though in most cases there is no real negotiation and the proposal is presented on a "take it or leave it" basis, there are cases when negotiation nonetheless does occur, before or after the vote, and results in the offer being improved or finally rejected.

67. This description is not true in every country. There are countries in which the corporate law substantially increases the administrative costs. For example,

in some countries, shareholders must show up in person or send an authorized representative to a shareholders' meeting to be able to vote .... In Japan, for examplc, annual shareholder meetings are concentrated overwhelmingly on a single day in late June, and voting by mail is not allowed for some shareholders.... [1]n some countries, law requires that shareholders deposit thcir shares with the company or financial intermediary several days prior to a shareholder mecting.... This practice prevents shareholders from selling their shares for several days around the time of the meeting.

Rafael La Porta et al., Law and Finance, 106 J. PoL. Econ. 1113, 1127 (1998).

68. See Nitzan \& Procaccia, supra notc 11.

69. See, e.g., Bernard S. Black, Agents Watching Agents: The Promise of Institutional Investor Voice, 39 UCLA L. REv. 811 (1992) (discussing positive aspects of institutional investor participation, such as the limited incentives of money managers to breach fiduciary duties or other legal rules, the ability of money managers to watch cach other, the role of divcrsification in giving money managers incentives to preserve rcputation and in reducing incentives to cheat, money managers' fear of political reaction to abusc of institutional power, and the need to balance the risk of institutional abuse of power against the certainty of corporate manager abuscs under the existing system).

70. See, e.g., Edward B. Rock, Controlling the Dark Side of Relational Investing, 15 CARDozo L. REv. 987 (1994) (focusing on the problems inherent in the notion of "relational investor"); Edward B. Rock, The Logic and (Uncertain) Significance of Institutional Shareholders Activism, 79 GEO. L.J. 445 (1991) (pointing to the risks associated with active institutional investors); Roberta Romano, Public Pension Funds Activism in Corporate Governance Reconsidered, 93 Colum. L. Rev. 795 (1993) (arguing that public pension funds face distinctive investment conflicts that limit the benefits of their activism). 
Third, the voting process is susceptible to strategic voting. Some of the voters can adopt a holding-out strategy and turn down an efficient transaction in order to raise the price of their consent. The proponent of the deal can adopt a strategy of "signaling": By refusing to bow to extortion, the proponent acquires the reputation of a staunch negotiator and thereby discourages future holding-out attempts. If the minority consists of a very large group of voters among whom coordination is impractical, a holdingout strategy will not be pursued. If, however, the minority is made up of a few individuals who might easily join together, then holding out will again become a significant risk. The presence of institutional investors could exacerbate the problem of holding out, since these investors can communicate amongst themselves with relative ease to form a coalition. However, it is reasonable to assume that their activities will not exceed the boundaries of tough negotiating. They will not demand an extortionist price that will cause the transaction to fall through, since they are able to correctly assess the profit to be gained from its performance.

Finally, an important element in evaluating negotiation costs is the expected frequency (the number of occurrences) and quality (the division between the expected value of efficient and inefficient transactions) of selfdealing transactions. Since a majority-of-the-minority rule applies to all regulated $^{71}$ cases, where a high frequency of self-dealing transactions is expected-for example, where concentrated ownership and cross-holdings of firms are prevalent-negotiation costs will substantially increase, and vice versa. Other things equal, ${ }^{72}$ calling shareholders meetings too frequently could increase negotiation costs beyond the expected adjudication costs incurred by switching to a liability rule.

Given an existing frequency, the expected quality of self-dealing transactions will also influence the relative amount of the negotiation costs. Assuming a minimum level of judicial efficiency, when inefficient transactions far outnumber efficient transactions, a property rule is preferable since the expected damage from the loss of a small portion of the efficient transactions and the increased administrative costs are outweighed by the expected damage from the ratification of too many inefficient transactions. On the other hand, when there are more efficient transactions, the risk of

71. Every system can define the type of self-dealing transaction that will be regulated, i.e., will be bound by either the fairness test or the majority-of-the-minority rule. For example, a system can dctermine that every self-dealing transaction is regulated, or it can restrict the regulation to transactions involving a conflict with a shareholder holding $10 \%$ or more of the shares or involving a substantial amount of the corporate capital.

72. Indeed, the rule itself, in turn, can influence the frequency and quality of transactions involving self-dealing. For instance, a majority-of-the-minority rule entails the costs of securing the minority's support, but the probability of success in this effort is low if expropriation is contemplated. These costs should deter some transactions, both inefficient and efficient, and thus will decrease their frequency. 
approving inefficient transactions is small, and a liability rule is preferable to save the negotiation costs associated with the property rule.

\section{B. Adjudication Costs}

Adjudication costs arise under both property rules and liability rules. The property rule predicates the performanee of a transaction on the ability to secure the consent of the disinterested members of the group. This consent reflects a range of subjective assessments on the part of the voters. Generally speaking, court intervention to evaluate the quality of the transaction is unnecessary since the transaction will take place under market conditions.

The voting process itself, however, is susceptible to distortions. For example, voters may be provided with misleading or insufficient information; management or the controlling owner often holds proxies from the "disinterested" voters; voters may be promised benefits and thus no longer be "disinterested"; intimidation of voters with threats of retaliatory behavior may occur; or there may be hidden or unknown business or personal ties between voters and management or between voters and the controlling owner. $^{73}$

The risk of a flawed ballot involves the court in determining whether proper procedures were followed and whether those voting were, indeed, disinterested parties. As contrasted to evaluating the transaction's merits, here the court's role is relatively uncomplicated. The court should have no difficulty in reviewing the procedures followed as well as the information that was provided to the voters. ${ }^{74}$ By the same token, while it is difficult to determine whether a given voter is indeed interested, it nevertheless will not entail high costs, since the courts are accustomed to contending with issues of deceit. ${ }^{75}$ In addition, the probability of a large number of

73. See, e.g., Citron v. E.I. du Pont de Nemours \& Co., 584 A.2d 490, 520 (Del. Ch. 1990) (citing with approval Kahn v. Lynch Communication Sys., 638 A.2d 1110 (Del. 1994)).

74. See, e.g., Virginia Bankshares, Inc., v. Sandberg, 501 U.S. 1083 (1991) (holding that knowingly false statements might have been actionable, but that minority shareholders failed to demonstrate the equitable basis rcquired to cxtend the private action available under the Securities Exchange Act to thcm); In re Tri-Star Pictures, Inc., Litig., 634 A.2d 319 (Del. 1993) (stating that information is required to pass the entirc fairness test); Bershad v. Curtiss-Wright Corp., 535 A.2d 840 (Del. 1987) (holding that there is no breach of fiduciary duty of candor where the proxy statement fully informed minority shareholders of all material facts); Weinberger v. UOP, Inc., 457 A.2d 701 (Del. 1983) (holding that failure to disclose full information is actionable); Lynch v. Vickcrs Energy Corp., 383 A.2d 278 (Del. 1977) (holding that failure to disclose the substance of a report and an authorization of open-market purchases at $\$ 15$ per share was, in each instancc, a violation of the fiduciary duty owed to the minority stockholders); In re Trans World Airlines, Inc. S'holders Litig., No. 9844, 1988 Del. Ch. LEXIS 139 (Del. Ch. Oct. 21, 1998) (holding that if the minority shareholders were not fully informed, or the special committee failed to understand its function, the burden would rest on the defendant to show that it met the entire faimess standard).

75. In fact, Dclaware courts are shifting from judging valuation issues towards judging the procedures employcd in the vote. See infra text following notc 112 . 
irregularities taking place in the voting process is small. Because large voter participation greatly increases the chances that irregularities are discovered, irregularities are diseouraged. For these reasons, a property rule should involve low adjudication costs. ${ }^{76}$

A liability rule, on the other hand, rests upon a protection that demands routine intervention by the courts. Courts will be called upon as a matter of course to decide whether a given self-dealing transaction is objectively fair. This does not mean that all transactions where a conflict of interest arises will entail litigation, since in many cases the minority will consider the proposed transaction to be fair while in other cases negotiation will yield a settlement. ${ }^{77}$ But those cases that do reach the courts will necessitate an examination of the merits of the deal in a process that will generate considerable adjudication costs. It will be necessary to elicit expert opinions as to the value of the transaction, ${ }^{78}$ and the courts will be compelled to decide between the inevitably differing opinions that will be tendercd in order to fix the "correct" value of the transaction. ${ }^{79}$

Determining the objective value of a transaction is a complicated process that requires a high degree of competence from the courts since such valuations involve future projections of different variables, all of which can affect the actual price, and the use of complex financial models. ${ }^{80} \mathrm{~A}$ liability rule based on judicial rulings, therefore, relies on the existence of professional institutions capable of providing accurate assessments as well as competent courts possessing the necessary level of expertise to

76. It should be emphasized, however, that the ability of courts to enforce a property rule in a predictable and eonsistent manner is the minimum level of effieiency and effectiveness required of any judicial system. High adjudication costs in enforcing a property rule (because of an inefficient or corrupt court system) create in effect a system of nonintervention where parties are unable to contract around the absenee of minority protection. Indeed, there are countries in which the system of legal cnforcement is so weak that the mere existence of minority shareholders' right to vote does not provide them with any meaningful protection due to their inability to enforce their rights. See La Porta et al., supra note 38; La Porta et al., supra note 67. Thus, this kind of "protection" should be regarded more as a nonintervention regime than a property rule.

77. See, e.g., Joel Seligman, Reappraising the Appraisal Remedy, 52 Geo. WaSH. L. Rev. 829 (1984) (noting that during the years 1972-198I, inclusive, there were 16,479 mergers of U.S. corporations but only approximately 20 reported cases involving appraisal).

78. See Weinberger, 457 A.2d at 714 (holding that all commonly accepted evaluation methods must be taken into account).

79. See supra note 31 .

80. The case of Cede \& Co. v. Technicolor, Inc., No. CIV.A.7129, 1990 WL 161084 (Del. Ch. Oct. 19, 1990), is an extreme example. In Cede, evidence was presented from more than 21 witnesses over the course of 47 days of trial. On appeal, the Supreme Court of Delaware reversed and remanded the case for further proceedings. Cede \& Co. v. Technicolor, lnc., 684 A.2d 289 (Del. 1996). Fifteen years after the case was first filed, a new appraisal proceeding started with the appointment of a neutral expert witness. Cede \& Co. v. Technieolor, Inc., No. CIV.A.7129. 1999 WL 65042 (Del. Ch. Jan. 29, 1999). Another telling example is In re Shell Oil, No. CIV.A.8080, 1990 Del. Ch. LEXIS 199 (Del. Ch. June 25,1990 ), in which the parties presented 644 trial exhibits, and the trial transeript exceeded 1000 pages: 
rule effectively in such areas. The professional standards of these institutions and courts determine the direct adjudication costs.

The indirect adjudication costs are also influenced by the efficiency of the adjudicating process. Indirect adjudication costs depend on the frequency of wrong decisions in a given system. Any deviation from economic efficiency - the approval of an unfair transaction or the rejection of a fair one-means increased costs. The use of objective standards simplifies the task of evaluations since it is easier to place an objective value on an asset than to determine a subjective value. It is important to remember, however, that where no market price exists, an "objective" value is the product of subjective assessments, ${ }^{81}$ and the risk of mistakes is thus not eliminated. The number of faulty decisions is reduced if professional institutions are more trustworthy and impartial, and the courts are more competent. When, on the other hand, the professional institutions slant their opinions to the benefit of those soliciting them, or when the courts are incompetent, overburdened, and/or corrupt, the number of wrong decisions is much larger, and their attendant costs are much more significant.

High indirect adjudication costs can inflict a severe blow to economic efficiency. First, they affect the willingness of investors to invest in corporations as a minority group. Second, they place unnecessary burdens on the majority to create reliable and cost-effective alternative defenses to secure potential investors. Third, they frustrate effective negotiations that might have otherwise occurred in the shadow of the rule. The savings in information costs gained by the existence of legislatively imposed protection will be outweighed by the adjudication costs, as the market will, in any case, be forced to provide its own solutions.

Importantly, here too, the expected frequency and quality of selfdealing transactions will affect the relative costs because a faimess test only applies to challenged cases while a majority-of-the-minority rule applies to all regulated cases. Thus, other things equal, ${ }^{82}$ high frequency could result in calling shareholders meetings too often under a property rule with the result that negotiation costs exceed a liability rule's expected adjudieation costs.

Similarly, given an existing frequency, the expected quality of selfdealing transactions also influences the adjudication costs. When inefficient transactions are more common, a property rule is preferable since the expected damage from the loss of a small portion of the efficient transactions and increased administrative costs are outweighed by the expected

81. See Kaplan v. Goldsamt, 380 A.2d 556, 567 (Del. Ch. 1977) (basing an evaluation on several subjective opinions).

82. Indeed, the rule itself, in turn, can influence the frequency and quality of transactions involving self-dealing. For instance, if, under a fairncss test, the probability of securing court approval for expropriation is high (due to inefficient or corrupt courts), the frequency will increase while the quality will decrease. 
damage from the ratification of too many inefficient transactions. On the other hand, when efficient transactions are more common, the risk of approving inefficient transactions is small, and a liability rule would be preferable to save the negotiation costs associated with the property rule.

A comparison of adjudication costs to negotiation costs may indicate that one rule is more appropriate than the other in a given context, but these considerations alone do not complete the picture. As described below, market mechanisms also influence these costs.

\section{Market Mechanisms}

Market mechanisms operating in tandem with the legal system have the potential to combat the problems arising from self-dealing. The efficacy of these mechanisms may be a determinative factor in ensuring economic efficiency because of their effect on adjudication and negotiation costs. Thus, if the legal system generates prohibitive adjudication costs, these mechanisms are likely to produce less expensive means of enforcement or to reduce negotiation costs to a point where recourse to the courts is unnecessary. Therefore, the choice between a liability rule and a property rule must also take these mechanisms into account.

\section{The Market for Corporate Control}

One mechanism which has generated a great deal of attention as a remedy for the agency problem and the related problem of self-dealing is the market for corporate control. ${ }^{83}$ When a corporation is mismanaged, its shares lose value, and the company becomes a potential target for a takeover. Spotting an opportunity to turn a profit by employing more efficient management, a tender offeror acquires shares at a rate that allows him to replace the management and raise the company's value to efficient standards. The market for corporate control thus corrects inefficiency both by imposing a potential threat of a takeover as a deterrent to poor management and by taking steps to improve efficiency after a takeover has actually been executed. $^{84}$

Self-dealing transactions with unfair price tags, a type of mismanagement, may cause a company's share price to fall, and minority

83. See, e.g., Ronald J. Gilson, Seeking Competitive Bids Versus Pure Passivity in Tender Offer Defense, 35 Stan. L. Rev. 51 (1982); Lucian A. Bebchuk, The Case for Facilitating Competing Tender Offers: A Reply and Extension, 35 StAN. L. REv. 23 (1982).

84. See Frank H. Easterbrook \& Daniel R. Fischel, The Proper Role of a Target's Management in Responding to a Tender Offer, 94 HARV. L. REV. 1161 (1981) (arguing that resistance by a corporation's manager to a premium tender offer, even if it triggers a bidding contest, ultimately decreases shareholder welfare); Henry G. Manne, Mergers and the Market for Corporate Control, $73 \mathrm{~J}$. POL. ECON. 110 (1965) (arguing that mergers and acquisitions offer a lessening of wasteful bankruptcy proceedings, more efficient management of a corporation, protection to noncontrolling corporation investors, increased liquidity in capital, and a more efficient allocation of resources). 
shareholders' concern over losing their investment may cause a drop in share value, increasing the company's exposure to the risk of takeover. However, when the market for corporate control is effective, there are few cases of exploitation of the minority. Therefore, even under a liability-rule regime, the number of cases in which it is necessary to have recourse to the courts is low, regardless of adjudication costs.

The effectiveness of the market for corporate control depends, inter alia, on the prevalence of potential tender offerors who monitor the markct to locate inefficient corporations, the efficiency of the capital markets that provide the large sums needed for takeovers, and the existence of a legal regime that makes it difficult for the current controlling owners to prevent takeovers. In addition, the most important factor for the existence of a market for corporate control is the governancc structure of the corporation: dispersed ownership or concentrated ownership. When concentrated ownership is prevalent in the market, takcovers are rare. When a person holds effcctive control of the company with less than $50 \%$ of the outstanding shares, it is possible to gain a larger percentage of holdings and take control. By holding an absolute majority of shares, however, a controlling owner can render the company immune to takeovers. ${ }^{85}$ No matter how inefficient the controlling party may be, as long as it holds an absolute majority, it cannot be usurped other than through a consensual, private transaction. ${ }^{86}$

When the market for corporate control is ineffective, with the result that there is no threat of hostile takeovers, the minority is less protected. Consequently, under a liability rule, the minority has to rely on the judicial system and bears the burden of significant adjudication costs. On the other hand, under a property-rule regime, the protection afforded by the markct for corporate control is unnecessary. A property-rule protection protects the minority's interest more effectively than the threat of a takeover since the minority's consent is required to approve a self-dealing transaction. Under such a system, since the minority is not expected to extend its support to an inefficient transaction, exploitation of the minority is a difficult task, ${ }^{87}$ therefore, control has little value to an entity interested in profiting at the minority's expense. Likewise, the potential profits to be had from a takeover motivated by the removal of a party acting to the minority's detriment

85. See Zohar Goshen, Controlling Corporate Agency Costs: A United States-Israeli Comparative View, 6 CARdozo J. INT'L \& Comp. L. 99 (1998) (comparing the case of lsrael, in which concentrated ownership precludes a market for corporate control, with the case of the United States, in which dispersed ownership facilitates a market for corporate control).

86. Private sales of control involve agcncy problems as well. See CLARK, supra note 26, at 479.

87. This statement must be qualified. If courts are incfficient in enforcing a property rule, shareholders are unable to effectively prevent incfficient transactions and expropriation thus becomes possiblc. Consequently, in such a situation, an efficient market for corporate control will improve the protection for the minority. 
is low, and thus the incentive to initiate such a takeover is minimal. Indeed, negotiation costs are the only costs that remain.

\section{The Capital Market}

Corporations seeking to raise capital to finance their business activities often turn to the capital markets. Among those active in the capital markets are professional investors, such as underwriters and investment banks, which act as brokers between corporations and potential investors. Investments are evaluated by the corporation's past performance and its future plans. ${ }^{88}$ Efficient corporations are able to raise capital on favorable terms, whereas inefficient corporations find capital available to them only on expensive terms, if at all. ${ }^{89}$ Corporations in which the majority exploits the minority have difficulty raising additional capital; under such circumstances, investors are unwilling to enter the corporation as part of the minority. By contrast, corporations structured to protect the minority will raise capital easily and cheaply. Accordingly, the capital market should protect the minority, even under a liability-rule regime where adjudication costs are high. Of course, the capital market must be an efficient market in order to provide such protection. ${ }^{90}$

Yet, the effectiveness of even an efficient capital market as a protective mechanism is limited. In the United States, for example, most public corporations fund their activities by rolling over undistributed profits rather than by raising capital from the public..$^{91}$ Thus, if the corporation does not have to turn to the capital market to raise funds, that market cannot control the majority's ability to expropriate minority shareholders.

Although an efficient capital market cannot, by itself, control expropriation of the minority, it does serve an important function: informing market participants about existing and potential expropriations and incorporating this information into the price of the stock. This function is crucial for the proper operation of other more effective market mechanisms.

\section{Sophisticated Investors}

The composition of the minority shareholders also affects the choice of appropriate protection. When the minority consists mainly of sophisticated investors, such as institutional investors, the market operates as an

88. See Merritt B. Fox, Finance and Industrial Performance in a Dynamic Economy (1987).

89. See Lynn A. Stout, The Unimportance of Being Efficient: An Economic Analysis of Stock Market Pricing and Securities Regulation, 87 MiCH. L. Rev. 613 (1988).

90. See Ronald J. Gilson \& Reinier H. Kraakman, The Mechanisms of Market Efficiency, 70 VA. L. REv. 549 (1984) (analyzing the mechanisms of efficient markets); Jeffrey N. Gordon \& Lewis A. Kornhauser, Efficient Markets, Costly Information, and Securities Research, 60 N.Y.U. L. Rev. 761 (1985) (analyzing the consequences of efficient markets).

91. See, e.g., Zohar Goshen, Shareholder Dividend Options, I04 YALE L.J. 88I, 882 (1995). 
effective protective mechanism. Sophisticated investors invest in the collection and evaluation of information and act in accordance with their findings on a consistent and professional basis. ${ }^{92}$ Such investors are capable of pricing securities so as to incorporate the risk of self-dealing. These investors are active in the market on a long-term basis, behave consistently, and can thus properly appreciate a good reputation and punish a bad one. ${ }^{93}$ It is easy to administer informed votes, and the risks of errors and holdouts in such votes are low. Consequently, in such a market, negotiation costs under a property rule are low. To the extent that the presence of sophisticated investors deters the occurrence of exploitation through self-dealing, adjudication costs decrease as well, due to the reduced need to resort to the eourts.

It should be emphasized, however, that an effective judicial system is more important than the presence of sophisticated investors. To illustrate, suppose that a perfect judicial system exists: It has low direct adjudication costs and makes no mistakes. In this case, a liability rule would be preferable. Since the parties would know that the courts do not err, they would negotiate in the shadow of the rule, and the optimum number of efficient transactions would take place without any need to actually resort to the courts. By contrast, a property rule would cause waste by mandating formal negotiations through vote in all cases, even though there is no risk of expropriation. Now suppose that an inefficicnt and/or corrupt judicial system coexists with a market dominated by sophisticated investors. Clearly, a liability rule would result in high adjudication costs. But, even a property rule would not function properly, since its enforcement would also be dependent on the courts. In other words, high adjudication costs translate into high negotiation costs. Indeed, the minimum efficiency level required of a court is the ability to enforce a property rule with some predictability and consistency ${ }^{94}$ Only then can a property rule's negotiation costs in a system with sophisticated investors be lower than a liability rule's adjudication costs.

Moreover, in a market dominated by sophisticated investors who have recourse to sufficiently efficient courts, even a noninterventionist approach can arrive at efficient results, since the parties involved-the corporations and the investors - can devise the proper defense. When minority investors are generally unsophisticated, however, the mandatory protections imposed by law assume greater importance.

92. See, e.g., Black, supra note 69 .

93. See Bernard S. Black \& John C. Coffee, Jr., Hail Britannia? Institutional Investor Behavior Under Limited Regulation, $92 \mathrm{MICH}$. L. REV. 1997 (1994) (suggesting that Britain presents a model of active institutional monitoring and that U.S. sccurities markets might look likc it if U.S. institutional holdings continue to grow).

94. See Katharina Pistor et al., Law and Finance in Transition Economies, in 8 ThE Economics of Transition 325 (2000). 


\section{Corporate Reputation}

The market mechanisms discussed above are based on the economic sanctions facing a controlling owner who harms the minority. For instance, the market for corporate control threatens management's jobs, while the capital market punishes abuses by pricing shares according to the willingness of investors to invest in the company as a minority. Sometimes, however, a social, rather than an economic, sanction plays a role in preventing abuse of the minority. ${ }^{95}$

The role of reputation in the business community is a nonlegal factor that reduces the risk of expropriation of minority shareholders. ${ }^{96} \mathrm{~A}$ controlling owner who is interested in receiving public approval and maintaining a positive image as an honest and moral dealer will refrain from abusing the rights of the minority-even when no economic sanction is threatened. ${ }^{97}$ Reputation, in short, reduces the prevalence of inefficient self-dealing transactions. Thus, in a business community where the personal reputation of controlling owners plays a significant role, a liability rule can produce effective results due to the reduced need to resort to the courts.

ln sum, the property-rule/liability-rule analysis of the relative costs of the different rules regulating self-dealing leads to the conclusion that there is no one efficient solution suitable to all cases. The preferable solution will depend on the specific economic, judicial, and social characteristics of a given jurisdiction.

\section{A Comparative Overview and Analysis}

The following brief comparative survey analyzes the protections provided to minority shareholders in five different jurisdictions according to the theoretical framework described above. This analysis reveals the comparative weight that each factor should have on the selection of a rule regulating self-dealing transactions. ${ }^{98}$

95. See Eugene F. Fama, Agency Problems and the Theory of the Firm, 88 J. Pol. Econ. 288 (1980) (pointing to reputation as a management restricting device); Roek, supra note 8 (illustrating the role of reputation in trusting eorporate managers).

96. See Black, supra note 69, at 831 (noting that nonregulatory eonstraints on managers include "cultural norms of behaviour"); Curtis J. Milhaupt, A Relational Theory of Japanese Corporate Governance: Contract, Culture, and the Rule of Law, 37 HARv. INT'L L.J. 3, 6-7 (1996) (diseussing cultural values in Japanese corporate structure).

97. Focusing on the social, rather than the eeonomic, incentives of the controller avoids the backward recursion problem of reputation models based on economic incentives. Supposc that at some point in the future, the economic benefits of maintaining a good reputation are lower than the costs to the controller of keeping her promise to the minority. At that point, the controller defaults. Investors who expect such an outcome will not finance the firm in the first place. The result is that reputation building is useless. See Jeremy Bulow \& Kenneth Rogoff, A Constant Recontracting Model of Sovereign Debt, 97 J. PoL. Econ. 155 (1989).

98. The jurisdictions ehosen for this analysis are those that are most commonly discussed in the comparative corporate law literature. 


\section{The United States (Delaware)}

Delaware, which is widely recognized as the most significant jurisdiction for corporate-law purposes, has adopted a liability rule as a default to govern self-dealing transactions. ${ }^{99}$ If challenged in court, the interested shareholder must demonstrate both fair dealing and a fair price to satisfy the "entire fairness" test. 100

For Delaware, a default liability rule is the right solution to the problems arising from self-dcaling transactions due to various characteristics of the U.S. markets and the Delaware judicial system. First, the Delaware courts possess unique expertise in appraising the value of transactions and in applying corporate law. In handing down decisions, the Delaware courts function with the efficiency, reliability, and speed crucial to a dynamic business world. ${ }^{101}$ Second, shareholding in the United States is widely spread among diverse investors; thus, an active market for corporate control is possible. ${ }^{102}$ Finally, the U.S. capital market is fairly efficient, ${ }^{103}$ sophisticated institutional investors hold a large segment of minority shares, ${ }^{104}$ and the business community in the United States is sensitive to business reputation with regard to the management of corporations. ${ }^{105}$

As a consequence, adjudication costs are low, both because of an efficient judicial system and because of the parallel activity of market mechanisms. But, negotiation costs are also low due to the presence of institutional investors and the efficiency of the capital markets. In such circumstances, market conditions resemble those of a market without transaction costs and any solution would provide efficient results. ${ }^{106}$ Therefore, a minimal and flexible protection is favorable as a default. ${ }^{107}$ Delaware's liability rule avoids the necd to hold a formal vote on every self-dealing transaction and requires courts to rule on only a minority of disputed

99. See ClaRK, supra note 26 , at 166 .

100. Weinberger v. UOP, Inc., 457 A.2d 701, 710-11 (Del. 1983).

101. Most other states, whose courts are not as proficient in corporatc law, have nonetheless adopted the liability-rule approach. Their choice could be due to two reasons: Other charaeteristics of the U.S. market may supply adequate protection for the minority despite high adjudication costs; this defense may be an outcome of the competition between states and may not necessarily reflect the attributes of the particular state. See Roberta Romano, Law as a Product: Some Pieces of the Incorporation Puzzle, 1 J.L. ECON. \& ORG. 225 (1985).

102. See Mark J. Roe, Some Differences in Corporate Structure in Germany, Japan, and the United States, 102 Y ALE L.J. 1927 (1993) (stating that a major difference in corporate ownership structure is that the coneentrated voting blocks that compose the governance structure of the largest German and Japanesc firms are abscnt in U.S. firms.)

103. See Gilson \& Kraakman, supra note 90.

104. See Black, supra note 69.

105. See Bernard S. Black, Is Corporate Law Trivial?: A Political and Economic Analysis, 84 Nw. U. L. Rev. 542, 573 (1990) (attributing the rarity of self-dealing in U.S. public corporations to the managers' internalization of a "developed sense of proper and improper behavior"); Rock, supra note 8, at 1103-05.

106. See supra Part Ill.

107. See supra Part I.B.4. 
cases. ${ }^{108}$ At the same time, however, parties are free to shift to a propertyrule protection via contract.

Indeed, Delaware courts allow parties to contract around the fairness rule and condition a deal upon approval of the majority of the disinterested minority. The approval of a self-dealing transaction by a majority of disinterested shareholders can affect the way the Delaware courts scrutinize a contested transaction in two ways. Where a controlling shareholder engages in self-dealing, the "entire fairness" test remains the standard by which the transaction is judged, but the burden of proof to show that the transaction is unfair passes to the party attempting to block its performance. ${ }^{109}$ When, however, the interested party is a director or manager without a controlling interest in the corporation, the transaction is measured against the business judgment rule, an entirely different standard, which is extremely deferential to the interested party. ${ }^{110}$ These doctrinal intricacies have led several prominent scholars to conclude that Delaware corporate law is a complicated, incoherent, and unexplainable system of rules. ${ }^{111}$ Howevcr, given the analytical framework provided above, I will show that Delaware rules are indeed coherent and provide an efficient means of controlling self-dealing.

In theory, under a property-rule regime, there is no need to determine whether the transaction is fair, since the minority can fend for itself. Therefore, when the parties choose to make sclf-dealing contingent upon the approval of a disinterested minority, it logically follows that such a transaction should be judged not by the fairness test, but by the business judgment rule just as any other nonconflicted third-party transaction would be. Delaware appears to follow this logic only part of the way, however. As noted above, a change in the judicial standard to the business judgment rule only applies to those transactions involving directors or managers who do not possess a controlling share. By contrast, transactions involving a controlling shareholder will still be subject to the fairness test, although the burden of proof will shift to the opponents of the transaction.

The stated rationale behind the courts' rcfusal to deviate from the fairness test in a controlling owner's self-dealing, even when a disinterested minority is secured, stems from procedural concerns. For example, a controlling shareholder may exploit hor position to distort the voting, whether by threatening the minority with future reprisals or by abusing the

108. See supra Part III.B.

109. See Kahn v. Lynch Communication Sys., 638 A.2d 1110 (Del. I994).

I10. See Michelson v. Duncan, 407 A.2d 2II (Del. 1979); In re Wheelabrator Techs., Inc., S'holders Litig., 663 A.2d 1194 (Del. Ch. 1995). This rule, in fact, treats the transaction as if it were a transaction with any other third party. See also supra note 7.

111. See supra note 8. 
wide discretion which proxies afford her. ${ }^{12}$ Indeed, the courts have kept the fairness test in order to provide themselves with sufficient ability and flexibility to tackle these procedural risks. Such ability and flexibility are absent under the business judgment rule.

Although the final result of Delaware's solution to the procedural risks is efficient, an alternative approach would distinguish between a controlling shareholder's ad hoc decisions to supplant the liability rule with a property rule and a consistent commitment to do so. When the condition that the majority of the minority must approve a self-dealing transaction is limited to a specific transaction, the controlling shareholder maintains the right to base other transactions (or even the present one) on the fairness test. In these circumstances, the courts' concerns about distortions in the voting process and intimidation of the minority are legitimate because the controlling shareholder could use the liability rule to initiate future transactions that are injurious to the minority (e.g., a freeze-out merger).

By contrast, when the parties determine that all self-dealing will be subject to the approval of the disinterested minority - for example, when this condition is set forth in the articles of incorporation-this concern is reduced. The controlling shareholder cannot force the current transaction upon the minority, nor can she harm the minority by future reprisals (for example, by injurious self-dealing or a freeze-out merger), since a majority of the minority will again be called upon to endorse the measure. Removing the threat of intimidation of the minority reduces the potential for irregularities in the voting process. Therefore, under such conditions, the business judgment rule can replace the fairness rule, even when a controlling shareholder is a party to the transaction.

Notwithstanding the above-suggested alternative approach, the fact that Delaware courts allow a controlling shareholder to shift the burden of proof to the contending shareholder upon receiving the support of the majority of the disinterested shareholders provides an additional efficient means to control self-dealing. To understand the effect of the Delaware rules, we should explore why the controlling person would condition the deal upon receiving majority-of-the-minority support, although the test remains "entire fairness," and only the burden of proof shifts. The answer lies in the repartition of the surplus. The controlling person faces two choices: to make the deal and bear the burden of proof that the deal is fair; or to make the deal with majority-of-the-minority support and shift the burden of proof to the party opposing the deal. In the first case, the controlling person could approve a deal on the lower side of the surplus. To obtain the approval of the minority, the controlling person would have to offer a higher price. The price, however, would not be as high as it would have

112. See Citron v. E.I. du Pont de Nemours \& Co., 584 A.2d 490 (Del. Ch. 1990) (emphasizing concern for possible future reprisals). 
been under a property-rule regime. Here, the negotiating power of the minority is limited by the knowledge that even if their support is not given, the controlling person can still make the deal and bear the burden of proof that it is fair. Nevertheless, the price offered to the minority must be higher than it would have been had their support not been sought. The effect of the rule shifting the burden of proof is, indeed, to provide the minority with some negotiating power: the minority has "something" to sell to the majority.

In effect, this is an insurance transaction: the controlling person pays a premium (increased price) to the minority in order to increase the chances that the deal will not be stalled by litigation or struck down by the courts. That is, in cases in which there is a risk that the court will err in determining the value of the deal, the controlling person can buy insurance (minority support), shift the burden of proof to the plaintiff, and increase the chance of maintaining the deal's validity. Therefore, shifting the burden of proof provides the market with the incentive to seek the support of the majority of the minority, thereby reducing the need for judicial judgment on the value of the deal. In fact, in terms of my analysis, courts prefer a shift from a liability rule-which would require the courts' ruling over valuation issues - to a property rule-in which case the courts' role is to judge the appropriateness of the voting procedure.

Many scholars believe Delaware's system to be a complicated, incoherent, and unexplainable system of rules. ${ }^{113}$ In fact, the particular characteristics present in Delaware law show that it has developed a coherent and very efficient solution to the self-dealing problem by establishing a liability rule as a default.

\section{The United Kingdom}

The United Kingdom shares many characteristics with the United States in terms of its capital markets and its economic and social environment. The capital markets of the United Kingdom are very liquid, composed of mostly public corporations, and benefit from a developed market for corporate control. ${ }^{114}$ Institutional investors have an extremely strong presence in the capital markets, controlling $70 \%$ of the shares of publicly traded companies. ${ }^{15}$ Furthermore, institutional investors have become much more active in monitoring and participating in the affairs of their

113. See supra note 8 .

114. See Black \& Coffee, supra note 93, at 2001.

115. See Brian R. Cheffins, Company Law: Theory, Structure, and Operation 64 (1997) (citing "Annual Meetings" (Lex Column), FIN. Times, October 2, 1995); Black \& Coffee, supra note 93, at 2002 ("U.K. institutions hold about two-thirds of all publicly traded British stocks, while U.S. institutions only hold around half of U.S. publicly traded stock."). 
portfolio companies over the last decade. ${ }^{116}$ Also, the business community is sensitive to business reputation. Indeed, the "British capital markets match those of the United States in being extremely active and well developed." 117

Given these characteristics, one would expect that, like the United States, the United Kingdom would adopt a fairness-test approach to selfdealing transactions. Indeed, the default rule followed in the United Kingdom is a liability rule. A majority shareholder is free to vote his shares at a shareholders meeting called to approve a transaction in which he has a personal interest. ${ }^{118}$ Even a director who is also a shareholder may vote on a transaction in which he is interested when the law requires that such transaction receive the prior approval of the shareholders. ${ }^{119}$ Against this freedom to vote with a conflict of interest, section 459 of the company law provides that minority shareholders can present a petition of "unfairly prejudicial" transaction, ${ }^{120}$ and courts have wide discretion in deciding upon the appropriate remedy. ${ }^{121}$ While the cases are few, the courts have held that section 459 provide protections to minority shareholders in conflict-of-interest transactions. ${ }^{122}$

116. CHEFFINS, supra note 115 (noting that institutional investors have in recent years become considerably more willing to take action in relation to companies in which they own shares).

117. John C. Coffee, Jr., Liquidity v. Control: The Institutional Investor as Corporate Mentor, 91 Colum. L. Rev. 1277,1309 (1991).

118. Paul L. Davies, Gower's Principles of Modern Company Law 707 (6th ed. 1997) (noting that "votes arc proprietary rights, to the same extent as any other incidents of the shares, which the holder may exercise in his own selfish interest even if these are opposed to those of the company").

119. Id. at 708 (citing Northwest Transp. Co. v. Beatty (1887) 12 App. Cas. 589; N. Countries Sec. Ltd. v. Jackson \& Steeple Ltd. (1974) I W.L.R. 1133). Davies describes the unbelievable ruling in the latter case: "[1]t was held that although, to comply with an undertaking given by the company to the court, the directors were bound to reeommend the shareholders to vote for a resolution they, as shareholders, could vote against it, if so minded." Id. at 708 n. 15 .

120. See Companies Act, 1985, c. 6, \$ 459(1) (Eng.). Section 459(1) provides:

A member of a company may apply to the court by pctition for an order under this Part on the ground that the company's affairs are being or have been conducted in a manner which is unfairly prejudicial to the interest of its members generally or some part of the members (including at least himself) or that any actual or proposed act or omission of the eompany (including an act or omission on its behalf) is or would be so prejudicial.

Id.

121. Section 461(2) of the 1985 Companies Act provides that a court may:

(a) regulate the conduct of the company's affairs in the future,

(b) require the company to refrain from doing or continuing an act complained of by the petitioner or to do an act which the petitioner has complained it has omitted to do,

(c) authorize civil proceedings to be brought in the name of and on behalf of the company by such person or persons and on such terms as the court may direct,

(d) provide for the purchase of the shares of any members of the company by other members or by the company itself and, in the case of a purchase by the company itself, the reduction of the company's capital aceordingly.

The 1985 Companies Act $\$ 461(2)$.

122. See DaviEs, supra note 118, at 735 . 
However, while section 459 theoretically seems to provide adequate protection for minority shareholdcrs in self-dealing transactions, in practice it has not. This failure primarily stems from the general nature of the judiciary in the United Kingdom. The vast majority of judges lack any expertise with the realities of the corporate world. ${ }^{123}$ In comparison with judges in the United States, especially those in Delaware, these judges do not "have the same experience with the mechanics of corporate deal-making" and do "not bring to the bench the same level of expertise as [their] Delaware counterpart[s]." 124 In addition, judges in the United Kingdom strictly adhere to the principle of stare decisis. ${ }^{125}$ Indeed, Parliament enacted section 459 with the express intent of changing the conservative approach of judges with respect to actions brought by minority shareholders. ${ }^{126}$ Despite Parliament's intent, the lack of judicial activism has resulted in the underutilization of section $459 .{ }^{127}$ Furthermore, even when the courts have ruled for minority shareholder petitions under section 459 , they have provided little guidance in their opinions for future claimants. ${ }^{128}$ In short, given the United Kingdom's inefficient and ineffective courts, liability-rule protection has not provided adequate protection due to high adjudication costs.

Nonetheless, the strong presence of institutional investors has led to effective private regulation, thereby minimizing the need to rely on court

123. See CHeffins, supra note 115, at 309 ("Ideally, judges will have sufficient awareness of key commercial dynamics to evaluate in a well-informed fashion the conduct of those involved in companies. There is some reason, however, that English judges are not particularly well-qualified on this count.").

124. Id. at 312 .

125. See id. at 333 ("Company participants can by and large depend on England's judiciary to stand by settled principles. English judges usually eschew judicial activism. As well, they are strongly inclined to follow rules set down in previous eases."); see also id. at 352 (stating that United Kingdom company law is more detailed and comprehensive than that of other countries, including the United States, in part because it attempts to "provide guidance to judges who are not well-suited to the task of applying rules which are expressed in the form of broad, general principles," because "the judiciary, when confronted with a situation where legislation fails to address directly a significant issue, has customarily been reticent to fill in the gaps").

126. See DAviEs, supra note 118, at 735-36 ("The section posed, moreover, when introduced in its modern form in 1980, a very considerable challenge to the traditionally noninterventionist attitudes of judges in relation to the internal affairs of companies." Specifically, section 459 was enacted with a change in wording from the previous statute, section 210 . Section 210 used the word "oppression" as the basis for minority shareholder action; however, it was interpreted very narrowly by the courts. Section 459 substituted the word "unfair prejudice" for "oppression," which was "a clear indication that Parliament intended the courts to take a more active role." Id. at 740.).

127. See CHEFFins, supra note 115 , at 335 ("English judges believe that a change in the law must be co-ordinated carefully with existing doctrine, which in turn means that the ramifications should be thought through carefully in advance. Consequently, they usually shy away from pursuing bold initiatives designed to reorganize legal principles.").

128. See id. at 330 (discussing the lack of coherence and clarity in the United Kingdom courts' decisions). 
rulings. ${ }^{129}$ The London Stock Exchange has stepped in and filled the void with its own rules for self-dealing transactions. ${ }^{130}$ According to section 11 of the listing rules, commonly called the "Yellow Book," to maintain a listing on the London Stock Exchange, corporations must submit all transactions involving a $10 \%$ shareholder to a general vote of the shareholders and deny the interested shareholder the opportunity to vote. ${ }^{131}$ This listing requirement in effect provides property-rule protection for minority shareholders. As such, the strong presence of institutional investors within the United Kingdom's commercial and social environment has led to lower negotiation costs under the property-rule protection. Thus, in the United Kingdom, private contracting has shifted the regulatory framework from a default liability rule to a property rule; accordingly, there has also been a shift from high adjudication costs to low negotiation costs.

\section{Canada}

The Canadian judicial system is not as well-versed in corporate law and appraisals of value as its U.S. counterpart, the market for corporate control is almost nonexistent because of the high concentration of holdings in most companies, and the local capital market is still inefficient, although institutional investors are gradually gaining greater influence and presence. ${ }^{132}$ In other words, this market is characterized by high adjudication costs without the market forces that could prevent these costs. These findings suggest that a property-rule protection would be most efficient.

However, the protections afforded to the minority shareholders under Canadian corporate law, in most jurisdictions, are based on a type of liability rule. The two most common protections are the remedy against the "oppression" of the minority and the appraisal right. "Nearly every Canadian corporate statute" affords minority shareholders the right "to

129. See id. at 364-420. Private regulation of corporate entities has long been a prevalent feature of the United Kingdom. In fact, the United Kingdom government has explicitly granted self-regulatory organizations powers over certain areas and has recognized them as the competent authorities in certain financial matters.

130. The London Stock Exchange is designatcd the competent authority for enforcing statutory guidelines, and its own listing requirements are given just a slightly lower status than statutory ones. Id. at 368 .

131. LONDON STOCK EXCHANGE LISTING RULES § 11 (2001), available at http://www.fsa.gov.uk/ pubs/ukla/chapt11-2.pdf. Sections 11.4(c) and (d) provide that in a transaction with a "related party," defined in section 11.1 (c) to include a greater than $10 \%$ shareholder, the company must

(c) obtain thc approval of its shareholders either prior to the transaction being entered into or, if it is expressed to be conditional on such approval, prior to completion of the transaction; and (d) where applicable, ensure that the related party itself abstains, and takes all reasonable steps to ensure that its associates abstain, from voting on the relevant resolution.

Id. $\S \S 11.4(\mathrm{c}),(\mathrm{d})$.

132. See Daniels \& Maclntosh, supra note 5; Jeffrey G. MacIntosh, The Role of Institutional and Retail Investors in Canadian Capital Markets, 31 OsGoode Hall L.J. 371 (1993). 
seek protection against majority or managerial 'oppression." "133 This remedy authorizes the courts to ignore technical rules binding the parties involved and to apply an unspecified combination of fair-play and legitimateshareholder-expectation standards. The statutes provide the court with extensive discretion to rectify the matters contested by the oppressed party. Among other powers, the courts have the authority to force the corporation or the oppressing party to buy out the oppressed party at a judicially determined fair price, or alternatively, to issue an order compensating the injured party. ${ }^{134}$

In addition, since the $1980 \mathrm{~s}$, most Canadian jurisdictions have provided for an appraisal right: a statutory mechanism whereby a minority dissenting to certain fundamental changes in corporate practiees can force the corporation to buy their shares at a judicially determined fair price. The appraisal right is usually triggered in cases such as mergers, major business changes, emigration from one jurisdiction to another, or on-going private transactions. ${ }^{135}$

Due to the ineffectiveness of Canadian courts, this liability-rule protection has proved inadequate. Consequently, dissatisfaction with the protections afforded in Canadian corporate laws has led bodies like the Ontario Securities Commission ("OS") to present a different view of the appropriate regulation to self-dealing transactions. In 1991, the OS issued a new rule, ${ }^{136}$ adding requirements that go beyond those found in the corporate laws. ${ }^{137}$ The OS rule requires majority-of-the-minority approval in certain large related-party transactions, ${ }^{138}$ and two-thirds majority of the minority if the transaction price deviates from the boundaries of the valuation prepared in connection with the related-party transaction. ${ }^{139}$ Without detailing all aspects of these requirements and their exemptions, the OS rule represents, in fact, a shift to property-rule protection (the majority-ofthe-minority rule) for transactions involving conflict-of-interest voting. Thus, there is a shift from high adjudication costs (due to ineffective courts) to lower negotiation costs (due to a gradual increase in the presence and effect of institutional investors). This shift of policy illustrates the tradeoff that was made by the OS. Although institutional investors are not yet as strong in Canada as they are in the United States and the United Kingdom, the cost involved in entrusting the protection against self-dealing

133. Bruce L. Welling, Corporate law in Canada, The Governing Principles 553 (2d ed. 1991).

134. Id. at $554,559,561$.

135. Id. at 572-75.

136. Ontario Securities Commission Rule 61-501 [hereinafter OS Rule]. The OS performs functions similar to the U.S. Securities and Exchange Commission.

137. See Daniels \& MacIntosh, supra note 5, at 900-12.

138. See OS Rule, supra note $136, \S 20$ (addressing transactions that exceed $25 \%$ of the issuer's market capitalization).

139. See id. §31. 
to them is lower than the cost associated with entrusting the protection against self-dealing to the courts.

\section{Germany}

When compared to the United States, thc German capital markets are at a low level of development. ${ }^{140}$ In addition, there is practically no market for corporate control due to the high concentration of holdings in tradable sharcs. ${ }^{141}$ However, in most corporations, the minority includes strong financial institutions which hold shares and also supply the corporation with credit. ${ }^{142}$ The close relationship of these institutions to the controlling owners, which is based on reputation and even on a dependency for credit, creates an efficient market in terms of the flow, evaluation, and use of information. ${ }^{143}$ However, because German courts are not as proficient as Delaware courts in applying corporate law and appraising value, ${ }^{144}$ these characteristics result in high adjudication costs and low negotiation costs. This combination of characteristics suggests that there should be a preference for adopting a flexible default rule. Indeed, German law is based on a liability-rule protection. ${ }^{145}$ As noted before, this is a more flexible

140. See Friedrich K. Kübler, Institutional Owners and Corporate Managers: A German Dilemma, 57 Brook. L. REv. 97 (1991) (offering an analysis of the relationship between a bank and a nonbank corporation in Germany). During the 1990s, important improvements took place in the eapital market, mainly due to the two Financial Market Promotion Acts: Gesetz zur Verbesserung der Rahmenbedingungen der Finanzmärkte (Finanzmarktförderungsgesetz), v. 22.2.1990 (BGBI. I S.266); Gesetz über den Wertpapierhandcl und zur Ändcrung börsenrechtlicher und wertpapierrechtlicher Vorschriften (Zweites Finanzmarktförderungsgesetz), v. 26.7.1994 (BGB1. I S. 1749).

141. See Theodor Baums, Corporate Governance in Germany: The Role of Banks, 40 Aм. J. Comp. L. 503, 504 (1992) (noting that only 700 of more than two million companies are registered on the exchange and that, of these, fewer than a hundred are widely held); Hwa-Jin Kim, Markets, Financial Institutions, and Corporate Governance: Perspectives from Germany, 26 LAW \& POL'Y 1NT'L Bus. 371, 380 (1995) (noting that most German corporations are not publicly traded and that it is estimated that only thirty German companics arc widcly held).

142. See Baums, supra note 141, at 503-08 (stating that, in addition to direct holdings, banks hold proxies from many investors from the public sector); John Cable, Capital Market Information and Industrial Performance: The Role of West German Banks, 95 EcoN. J. I18, 119 (1985) (noting that German companies tend to operate with a leveraged capital structure, which increases the influence of banks, who play a role in raising funds from outsidc sources); Kim, supra note 141, at 382-83 (observing that the rate of leverage for German companics is higher than for their U.S. counterparts and that they prefer to take credit from a single bank (Hausbank) instead of from several financial institutions).

143. Despite the fact that the disclosure regulation is inferior, see Hans-Michael Kraus, Securities Regulation in Germany? Investors' Remedies for Misleading Statements by Issuers, 18 INT'L LAW. 109 (1984), the position of banks as creditors provides them with more information than a normal investor, and their representatives are often present in bodies supervising managcment. See Baums, supra note 141 , at 512-14.

144. Many cases are brought in the so-called chambers for commercial affairs which fall under paragraph $95 \mathrm{ff}$. Gerichtsverfassungsgesetz (Judiciary Organization Act). Indced, these particular chambers specialize in cases involving corporate law and should develop a high level of proficiency over time.

145. The classic cxample of this liability rule is paragraph 243 of the Aktiengesetz (the German Stock Corporation Law) found in thc section dealing with void decisions of the assembly of 
protection that the parties involved can tailor to their specific needs. Nevertheless, unlike Delaware law, German law mandates liability-rule protection and leaves no freedom for the parties to contract for property-rule protection. It thus loses the efficiency gains that could be achieved from such contracts. ${ }^{146}$

\section{Italy}

Most Italian publicly traded corporations have a controlling owner (an individual or a group holding about $30 \%$ of the shares). ${ }^{147}$ Although such level of ownership leaves room for hostile takeovers, in practice, the market for corporate control is limited due to massive cross-holdings of firms, shareholders agreements, and high political involvement. ${ }^{148}$ In addition, there arc few sophisticated institutional investors, and the capital market is inefficient and underdeveloped. ${ }^{149}$ Moreover, Italian courts are ineffective and inefficient in providing predictable and timely judgments. ${ }^{150}$ Finally, the importance of reputation in the Italian business community is low. Thus, there is a substantial risk of high-frequency and low-quality

shareholders. See Hannes Schneider \& Martin Heidenhain, The German Stock Corporation ACT (1996) (translating the German Stock Corporation Act). Subsection 2 states that, when a controlling owner uses his voting power to achicve a special advantage for himself or a third party, the decision may be voided. However, when the decision has provided the injured shareholder with fair compensation, the paragraph does not apply. In other words the controlling owner can force the deal if he provides fair compensation. The lcgislation dealing with the activities of conglomerates (Verbundene Unternehmen) provides another example. These entitics have received special attention in parts of the Aktiengesetz (paragraphs 15-19 and 291-338). See id. The law allows a company to be subjected to another company on a contractual basis by a decision approved by a three-fourths majority of each company's shareholders (paragraph 293). The minority has no right of veto but is entitled to fair compensation (paragraph 304) or to having the controlling company purchase its shares at a fair rate (paragraph 305). If it is claimed that the compensation is unfair, the courts may intervene and determine a fair price. Similarly, violation of the arrangements dealing with conflicts of interests vis-àvis directors, such as paragraph 88 section 1 of the Aktiengesetz (which prohibits directors from exercising a business and from dealing in the corporation's area), paragraph 181 of the German Civil Code (which prohibits general self-contracting by agents), and paragraph 93 section 2 of the Aktiengesetz (which sets forth the duty of loyalty), results in a claim for fair compensation (e.g., paragraph 147 of the Aktiengesetz). See id.

146. Paragraph 23, section 5 of the Aktiengesetz sets the principle of "Satzungsstrenge" (rigidity of articles of incorporation) and mandates that the articles of incorporation cannot diffcr from the provisions of the Stock Corporation Law unless it is explicitly permitted. See id. Additional provisions are allowed unless the rules of the Stock Corporation Law provide for complete regulation of the mattcr.

147. See Marcello Bianchi et al., Pyramidal Groups and the Separation Between Ownership and Control in Italy, in The Control of Coporate Europe (Fabrizio Barca \& Marco Becht eds., 2001); Lorenzo Stanghcllini, Corporate Governance in Italy: Strong Owners, Faithful Managers, 6 IND. INT'L \& COMP. L. Rev. 91, 135-38 (1995).

148. Bianchi et al, supra note 147.

149. See La Porta et al., supra note 38, at 1137; Andrci Shleifer \& Robert Vishny, A Survey of Corporate Governance, 52 J. Fin. 737, 770 (1997); Stanghellini, supra note 147, at 135-36, 145-46, 155-56, 163.

150. Enriques, supra note 50 (providing empirical data on the ineffectiveness and inefficiency of Italian courts). 
self-dealing transactions. These findings suggest a need for minority protection based on a property rule, despite the fact that the frequency of selfdealing transactions is expected to be high (due to the massive crossholdings).

Some sections of Italian corporate law statutes offer what appears to be a property-rule protection, but other sections of the law and Italian courts' judgments establish what appears to be a liability-rule protection. Upon closer scrutiny, however, the Italian system is most accurately characterized as a nonintervention regime.

The law on the books restricts self-dealing voting in cases where a shareholder vote is required. ${ }^{151}$ The law does not, however, require that shareholders vote on every conflicted transaction, although all major corporate decisions (for example, mergers, sale of major assets, and change of bylaws) must be approved by shareholders. ${ }^{152}$ This law appears to establish a property-rulc protection. Yet a claim regarding a violation of the restriction on conflict-of-interest voting can succeed only if the plaintiff can show that the illegal vote was pivotal and that the price was unfair. ${ }^{153}$ Further, even if both elements are shown, only vcry rarely would the court issue a preliminary injunction to stop the transaction. These additional factors create what seems, in fact, to be an "off the books" liability-rule protection.

Moreover, Italian courts have held that the restriction on conflict-ofinterest voting does not apply to transactions between related corporations (for example, parent-subsidiary). ${ }^{154}$ Given the massivc cross-holdings of firms in Italy, most self-dealing transactions are therefore not governed by the property-rule protection. That is, these cases are governed by a liability rule. Moreover, the courts have held that in order to determine the existence of a potential harm and the extent of damages to a subsidiary, the indircct advantages deriving from bcing part of a group should be taken into consideration. ${ }^{155}$ In practice, this rule makes it extremely difficult to prove unfairness in a transaction between related corporations. Consequently, the transformation of the law on the books into a liability rule off

151. Voting with a conflict of interest is prohibited, and a majority of the minority must always be obtained where a vote over self-dealing is involved. Aldo Frignani \& Giancarlo Elia, ITALian COMPANY LAW 39 (1992) (translating Italian Civil Code, bk. V, art. 2373). In theory, under such a regime, as long as it can be assured that the voters have no ulterior interest in the transaction, and as long as the balloting was properly held, the terms of the transaction themselves need not undergo scrutiny. Indeed, the securing of proxies is highly regulated: The proxy must be in writing and remains valid for only one general meeting of shareholdcrs, the number of sharcholders that a single representative may represent is restricted, and proxies may not be granted to directors, corporate employees, or corporations controlled by the corporation (or their directors or employees), banks, or eredit institutions. $I d$.

I52. Id. at 35 (translating ltalian Civil Code, bk. V, art. 2365).

153. Id. at 39, 48 (translating Italian Civil Code, bk. V., arts. 2373, 2391).

I54. See GianFranco Campobasso, 2 Diritto Commerciale 283 (I999).

155. See id. 
the books, coupled with its minimal application and its evidentiary difficulty, provides very weak protection to the minority.

Notwithstanding the apparently very weak liability-rule protection, the Italian legal system should be treated as a nonintervention regime. Until I998, the law prevented the minority from bringing a derivative suit against the directors and managcrs-who usually approve and execute the conflicted transactions-by allowing the majority to renounce such a suit absent opposition of shareholders holding at least $20 \%$ of the capital. ${ }^{156}$ Moreover, it is difficult to contract around the legal deficicncies in minority protection because the validity of shareholders' agreements is uncertain. 157

The Italian legal system thus provides a striking cxample of a nonintervention regime. As explained earlier, such a system undcrmines the creation of a capital market. ${ }^{158}$ Indeed, the Italian capital markets are underdeveloped, and most of the economy is based on small and mediumsized nonpublicly traded corporations. ${ }^{159}$ In these corporations either there are no outside minorities (as opposcd to family members), or it is for some reason easier for the parties to creatc arrangements providing minority protections. ${ }^{160}$ Still, it is clear that facilitating a developed capital market will require that the law itself offer protections to minorities. Indeed, in I998 the Italian law went through a major reform; ${ }^{161}$ although this reform represents an important step, it will not be enough to bring about the required change. ${ }^{162}$

156. Articlc 2393 of the Italian Civil Codc, which dcals with actions for liability brought by the company (i.e., derivative suits), states:

The company may waive its right of action for liability and may compromise, provided that such waiver or compromise is approved by an express resolution of a shareholders' meeting, and provided that such resolution has not been opposed by a minority of shareholders representing at least one-fifth of the company's capital.

Frignani \& Elia, supra note 151, at 48 (translating Italian Civil Code, bk. V, art. 2393). See also Stanghellini, supra note 147, at 174. This rule was changed in 1998. See supra note 141.

157. See Stanghellini, supra notc 147, at 140-143, 181.

158. See supra Part 1.B.4.

159. See Stanghellini, supra note 147 , at 126-29.

160. See id. at 131-34.

161. See Legislative Decree 58 of 24 February 1998, Consolidated Law on Financial Intermediation pursuant to Article 8 and 21 of Law 52 of 6 February 1996 [hereinafter "the decree"].

162. The relevant changes concerning minority protection in the context of this Article are as follows.

a) Although the law still does not require shareholders to vote on self-dealing transactions, it does provide the minority with the right to call a shareholders' meeting. However, this right is reserved only to shareholders representing at least $10 \%$ of the corporation's capital (Article 125 of the decree). Furthcrmore, in an extraordinary shareholders' meeting there is a requirement of a high quorum $(50 \%$ of the sharcs on the first call, $33 \%$ on the second call, and $20 \%$ on the third call) and an affirmative two-thirds supermajority vote (Article 126 of the dccree). Given the large blocks of sharcs usually held by controlling sharcholders, it would be almost impossible for a minority shareholder to win a vote if the majority did not attend the meeting or voted against the minority position. 


\section{CONCLUSION}

Corporate self-dealing can be controlled by a number of means. This Article demonstrates that the choice between the two most preferable options is, in fact, a choice between liability-rule versus property-rule protection. This choice further depends on the total transaction costs incurred in a given system. These costs include both the negotiation costs attendant upon a property rule as well as the adjudication costs associated with a liability rule. The sum of these costs is influenced by the efficacy of the judicial system and the market mechanisms, including the market for corporate control, the capital market, and the types of investors active in the market. The U.S., British, Canadian, German, and Italian models each demonstrates that the relative weight of the different factors in a given system will affect the choice of the appropriate rule for the protection of the minority shareholders from the problem of self-dealing. In the end, the solution adopted must conform to the local conditions (that is, to the relative strength and weakness of the relevant empirical factors) in each jurisdiction. Indeed, there is no one efficient solution suitable to all.

b) There is some relaxation in the ability of the minority to bring a derivative suit. Shareholders representing at least $5 \%$ of the firm's capital can file a derivative suit, and this $5 \%$ can also block the majority from renouncing the suit (Article 129 of the decree). However, given that it is difficult for a minority to achieve representation of $5 \%$ of the capital, and given that there are no incentives beyond the pro rata share of the minority to bring the derivative suit (Article 129 of the decree provides only for reimbursement of the plaintiff's costs of action and only upon favorable judgment), the efficacy of these changes to promote dispersed ownership is doubtful.

c) The prospect of contracting around the law has improved. It is now possible to set in the corporation's bylaws a lower percentage than the $5 \%$ shareholdings required to have the right to file a derivative suit (Articlc 129(1) of the decree). However, no such right is provided rcgarding the 5\% shareholdings required to block the majority from renouncing the suit (Article 129(2) of the decree). Moreover, although the validity of shareholders' agreements was acknowledged, their duration was limited to three years (Articles 122 and 123 to the decree). 